\title{
Assessment of The Spatio-Temporal Distribution and Habitat Preferences of Ostracoda (Crustacea) Related to Certain Environmental Factors in Kapıdağ Peninsula (The Sea of Marmara, Turkey)
}

\section{Kapıdağ Yarımadası'ndaki (Marmara Denizi, Türkiye) Ostrakodların (Crustacea) Çevresel Faktörlere Bağlı Olarak Spatio-Temporal Dağılımı ve Habitat Tercihleri}

\author{
Ferda Perçin Paçal ${ }^{1 \oplus}$, Selçuk Altınsaçlı ${ }^{2 \oplus}$; Saltuk Buğra Arısal ${ }^{\circledR \oplus}$; Hüsamettin Balkıs ${ }^{4}$ \\ ${ }^{1}$ Istanbul University, Aziz Sancar Institute of Experimental Medicine, Department of Genetics, Şehremini, Istanbul, Turkey. \\ ${ }^{2}$ Merdivenköy Mahallesi, Ortabahar Sok. No: 20/4, Kadıköy, İstanbul, Turkey. \\ ${ }^{3}$ Nişantaşı University, Vocational School, Medical Laboratory Techniques, Bayrampaşa, İstanbul, Turkey. \\ ${ }^{4}$ Istanbul University, Faculty of Science, Department of Biology, Vezneciler, İstanbul, Turkey.
}

\section{ABSTRACT}

\begin{abstract}
The Sea of Marmara is exposed to pollutants in excess from the coastal industrial facilities and intensive urbanization, and because of that, the ecosystem is affected negatively. The aim of this study was to determine the environmental factors and ecological parameters on the species distribution and abundance of Ostracoda in Kapıdağ Peninsula coastline. At four seasons (April, July, October 2011 and January 2012), samples were collected from 21 stations (total of 84 samples) and 36 Ostracoda species were identified. The most distributed ostracod species were Carinocythereis antiquata, Aurila convexa, Loxoconcha gibberosa, Paradoxostoma fuscum, Cushmanidea elongata, and Xestoleberis decipiens. The highest numbers of individuals observed were Loxoconcha rhomboidea and Xestoleberis aurantia. During the study, water temperature varied between 7.5 and $30^{\circ} \mathrm{C}$, salinity varied between 12.1 and $29.2 \%$, $\mathrm{pH}$ varied between 6.6 and 8.7 , and dissolved oxygen varied between 1.2 and $15.3 \mathrm{mgL}^{-1}$ in the stations across the four seasons. Depth, mud percentage and the transparency of the water were the most effective factors on the living ostracod species of Kapıdağ Peninsula coastline according to spearman correlations.
\end{abstract}

Key Words

Kapıdağ Peninsula, ostracoda, ecology, distribution

öz

\begin{abstract}
$\mathrm{M}$ armara Denizi, kıyısında yer alan yoğun sanayileşme ve kentleşmeden dolayı kirliliğe maruz kalmakta, bu nedenle de ekosistemi olumsuz yönde etkilenmektedir. Bu çalışmada Kapıdağ Yarımadası kıyısındaki Ostracoda türlerinin dağıımı ve bolluğuna etki eden çevresel faktörlerin ve ekolojik parametrelerin belirlenmesi hedeflenmiştir. Dört mevsim boyunca (Nisan, Temmuz, Ekim 2011 ve Ocak 2012) 21 istasyonda (toplam 84 adet) örnek toplanmış ve 36 Ostracoda türü belirlenmiştir. En geniş dağılım gösteren türlerin Carinocythereis antiquata, Aurila convexa, Loxoconcha gibberosa, Paradoxostoma fuscum, Cushmanidea elongata, ve Xestoleberis decipiens olduğu görülmüştür. En fazla birey sayısı Loxoconcha rhomboidea ve Xestoleberis aurantia türlerinde saptanmıştır.Çalışmada dört mevsim boyunca sıcaklık $7.5-30^{\circ} \mathrm{C}$, tuzluluk \% $12.1-29.2, \mathrm{pH}$ 6.6-8.7, ve çözünmüş oksijen 1.2-15.3 $\mathrm{mgL}^{-1}$ aralıklarında belirlenmiştir. Spearman korelasyon analizine göre derinlik, çamur yüzdesi ve görünürlüğün Kapıdağ Yarımadası kıyılarında yaşayan ostrakod türleri üzerinde en etkili faktörler olduğu belirlenmiștir.
\end{abstract}

\section{Anahtar Kelimeler}

Kapıdağ Yarımadası, ostrakod, ekoloji, dağılım.

Article History: Received: Feb 25, 2019; Revised: May 18, 2019; Accepted: Jun 25, 2019; Available Online: Nov 1, 2019. DOI: https://doi.org/10.15671/hjbc.531987

Correspondence to: F. Perçin-Paçal, Aziz Sancar Institute of Experimental Medicine, 'Istanbul University, Şehremini, Istanbul, Turkey. E-Mail: ferda.pacal@istanbul.edu.tr 


\section{INTRODUCTION}

th he small bivalved crustaceans, ostracods, have laterally compressed bodies and two calcified valves. These crustaceans are diverse at very different environmental conditions $[1,2]$, including estuaries, seas, oceans, lagoons, lakes, ponds, streams, springs, rivers, peatlands, caves [3] and groundwaters from deep seas [4] to coastal and also terrestrial environments [5] Fossils and living ostracods have been used as important indicator organisms for recent paleoecological studies because of their great potential for ecological monitoring $[6,7]$. The ostracod species, widely distributed in aquatic areas, are important for ecological balance in terms of the separation of detritus and the nutrition of fish. Ostracods are also an important food source for invertebrates [5] and fish [8]. In both polluted and clean aquatic environments, ostracods are indicators of changes in marine habitats [9], which can be more reliable and more economic for environmental monitoring than long-term chemical analyses. Their composition, density, and diversity of assemblages are controlled by environmental parameters (salinity, temperature, $\mathrm{pH}$, oxygen, hydrodynamic conditions with the type of substratum) and also related to anthropogenic pollution (e.g. nutrient and heavy metal content) $[2,6,10]$. They are sensitive to anthropogenic pollution $[11,12]$ and can be used as indicators in marine, brackish, and freshwater environments [13-17].

The Sea of Marmara, which divides the Asian and European parts of Turkey, is a transitional waterway bet- ween the Black Sea and the Mediterranean Sea in the Turkish Strait System (TSS). This inner sea connects the Black Sea and the Aegean Sea with the Bosporus in the north and the Dardanelles in the south [18]. The Sea of Marmara which covers a surface area of $11,350 \mathrm{~km}^{2}$ is under pressure of pollution from large industrial establishments as well as the high population density and its domestic waste [19].

To date, 210 benthic ostracod species have been determined from the Sea of Marmara [20]. Also, 382 ostracod species have been reported in Turkish seas (326 from marine and 56 from coastal brackish waters) [21]. Perçin-Paçal and Balkıs, (2012) [22] reported 112 ostracod species (including most of the ostracod species identified in this study) together with their SEM photographs from Bandırma Bay and Erdek Bay, which compose the east end west side of Kapıdağ Peninsula. Our new data of the ecological parameters and species compositions are compared with the above-mentioned study by Perçin-Paçal and Balkıs, (2012) [22] and other studies $[23,24]$.

The present study aims to investigate the relationships of the recent ostracod species with different physicochemical parameters, a determination of spatio-temporal distributions, and habitat preferences of the species living between a depth of 0.5 and $30 \mathrm{~m}$ on the Kapıdağ Peninsula coastline. The secondary objective of this paper is to analyze the spatial and seasonal change of physicochemical and biological parameters considered to be caused by anthropogenic activities.

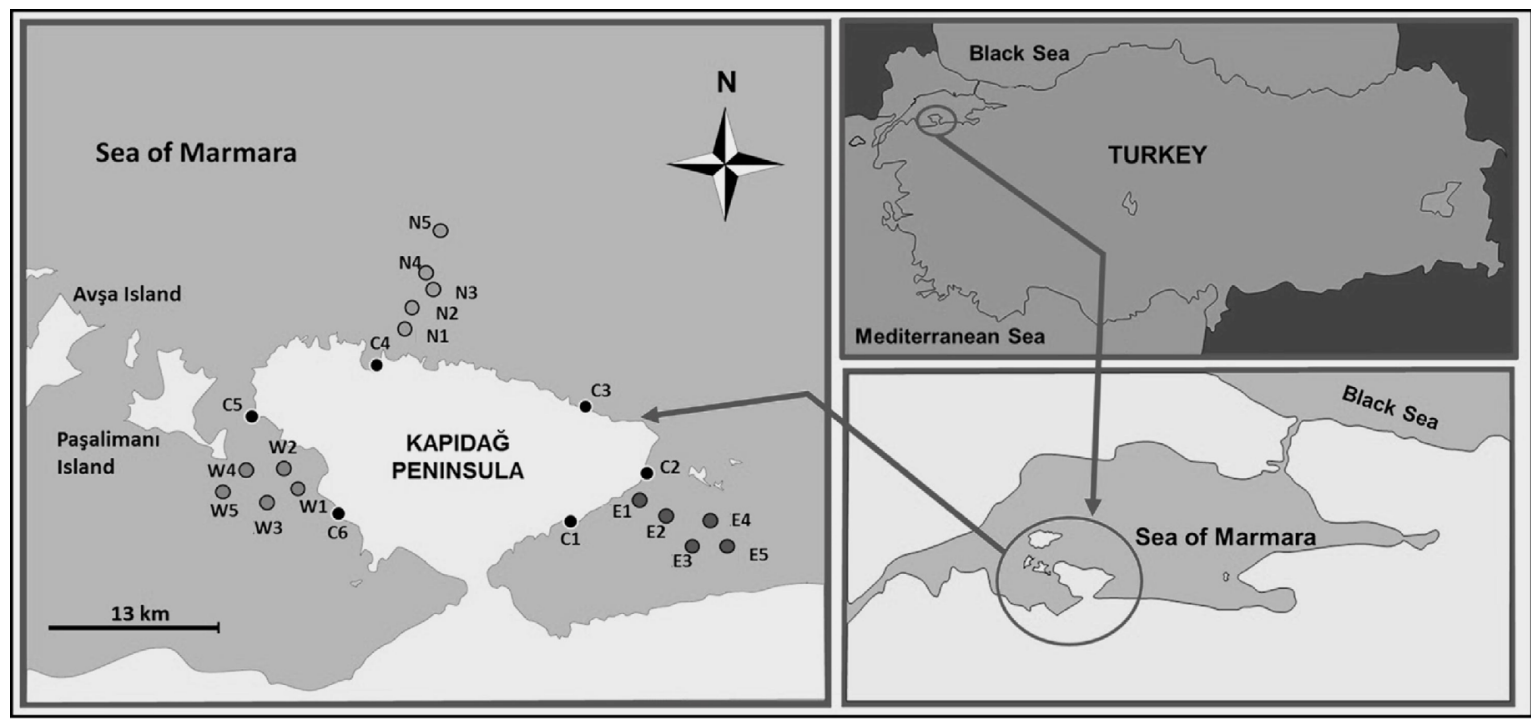

Figure 1. Locations of the sampling stations. 


\section{MATERIALS and METHODS}

\section{Study Area}

Kapıdağ Peninsula is located between Bandırma Bay (in the southeast) and Erdek Bay (in the southwest) on the southern coast of the Sea of Marmara (Figure 1). The area of the peninsula is approximately $290 \mathrm{~km}^{2}$. It is generally covered with bushes and, in some areas, forests, too. Tourism and fishing are widespread in the region. Erdek, covered with olive groves, fruit gardens, and vineyards, is a popular tourist center in the region. Bandırma Bay has a higher population density and industrial activities compared with Erdek Bay, meaning it is threatened by pollution from industrial and domestic waste as a result of industrial facilities surrounding it and population growth.

Bandırma is a developing industrial region and a major contributor to the regional economy and population growth with an organized industrial zone, founded in 1997 and located over an area of 150 hectares [25]. With the acceleration of industrialization, an additional area of 200 hectares was set aside to contribute to the development of trade. Bandırma Port is the second largest port in the Sea of Marmara after Istanbul Port [25]. In the future, Bandırma Port will become bigger, which will create negative environmental effects on the Sea of Marmara, which has already received most of Bandırma's pollution. Therefore, there is a strong possibility that the data from this study will contain valuable information for the future of the region.

The oceanographic characteristics of the coastline of Kapıdağ Peninsula are similar to the Sea of Marmara, and the water column has a two-layer structure. The surface water (the brackish Black Sea water) of the Sea of Marmara has a salinity of $17.6 \%$ and flows through the Bosporus to the Sea of Marmara. The waters of the Mediterranean originate with a salinity of about $38 \%$ and flow through the Dardanelles to the Sea of Marmara in a lower layer. According to the density differences between the two water layers, there is an intermediate (Halocline zone) salinity mass $25 \mathrm{~m}$ deep [19].

\section{Sampling Procedure}

The sampling was carried out from 21 stations at depths of $0.5,1,5,10,20$, and 30 m out from the southeast, southwest, and north sides of the peninsula in April, July,

Table 1. Results of human serum samples.

\begin{tabular}{|c|c|c|c|c|}
\hline Stations & Coordinates & Depth & Sediment type & Sampling equipment \\
\hline N1 & $40^{\circ} 30^{\prime} 48.1^{\prime \prime} \mathrm{N}-27^{\circ} 48^{\prime} 14.1^{\prime \prime} \mathrm{E}$ & 1 & \multirow{5}{*}{ Sand } & \multirow{21}{*}{ hand net (mesh size 50} \\
\hline N2 & $40^{\circ} 30^{\prime} 51.7^{\prime \prime} \mathrm{N}-27^{\circ} 48^{\prime} 15.8^{\prime \prime} \mathrm{E}$ & 5 & & \\
\hline N3 & $40^{\circ} 30^{\prime} 55.8^{\prime \prime} \mathrm{N}-27^{\circ} 48^{\prime} 21.4^{\prime \prime} \mathrm{E}$ & 10 & & \\
\hline N4 & $40^{\circ} 30^{\prime} 59.4^{\prime \prime} \mathrm{N}-27^{\circ} 48^{\prime} 21.3^{\prime \prime} \mathrm{E}$ & 20 & & \\
\hline N5 & $40^{\circ} 31^{\prime} 10.9^{\prime \prime} \mathrm{N}-27^{\circ} 48^{\prime} 27.4^{\prime \prime} \mathrm{E}$ & 30 & & \\
\hline W1 & $40^{\circ} 26^{\prime} 08.2^{\prime \prime} \mathrm{N}-27^{\circ} 44^{\prime} 55.0^{\prime \prime} \mathrm{E}$ & 1 & \multirow{3}{*}{ Sand and mud } & \\
\hline W2 & $40^{\circ} 26^{\prime} 08.4^{\prime \prime} \mathrm{N}-27^{\circ} 44^{\prime} 54.2^{\prime \prime} \mathrm{E}$ & 5 & & \\
\hline W3 & $40^{\circ} 26^{\prime} 08.5^{\prime \prime} \mathrm{N}-27^{\circ} 44^{\prime} 53.2^{\prime \prime} \mathrm{E}$ & 10 & & \\
\hline W4 & $40^{\circ} 26^{\prime} 11.4^{\prime \prime} \mathrm{N}-27^{\circ} 44^{\prime} 48.3^{\prime \prime} \mathrm{E}$ & 20 & \multirow{2}{*}{ Shell and mud } & \\
\hline W5 & $40^{\circ} 26^{\prime} 11.0^{\prime \prime} \mathrm{N}-27^{\circ} 44^{\prime} 46.1^{\prime \prime} \mathrm{E}$ & 30 & & \\
\hline E1 & $40^{\circ} 26^{\prime} 38.7^{\prime \prime} \mathrm{N}-28^{\circ} 00^{\prime} 32.2^{\prime \prime} \mathrm{E}$ & 1 & \multirow{5}{*}{ Mud } & \\
\hline E2 & $40^{\circ} 26^{\prime} 39,1^{\prime \prime} \mathrm{N}-28^{\circ} 00^{\prime} 32.5^{\prime \prime} \mathrm{E}$ & 5 & & \\
\hline E3 & $40^{\circ} 26^{\prime} 37.2^{\prime \prime} \mathrm{N}-28^{\circ} 00^{\prime} 33.4^{\prime \prime} \mathrm{E}$ & 10 & & \\
\hline E4 & $40^{\circ} 26^{\prime} 35.5^{\prime \prime} \mathrm{N}-28^{\circ} 00^{\prime} 31.6^{\prime \prime} \mathrm{E}$ & 20 & & \\
\hline E5 & $40^{\circ} 26^{\prime} 32.5^{\prime \prime} \mathrm{N}-28^{\circ} 00^{\prime} 30.8^{\prime \prime} \mathrm{E}$ & 30 & & \\
\hline $\mathrm{C} 1$ & $40^{\circ} 25^{\prime} 22.7^{\prime \prime} \mathrm{N}-27^{\circ} 57^{\prime} 17.7^{\prime \prime} \mathrm{E}$ & 0.5 & \multirow{6}{*}{$\begin{array}{l}\text { Mytilus galloprovincialis, } \\
\text { photophilic algae }\end{array}$} & \\
\hline $\mathrm{C} 2$ & $40^{\circ} 27^{\prime} 35.9^{\prime \prime} \mathrm{N}-28^{\circ} 01^{\prime} 23.7^{\prime \prime} \mathrm{E}$ & 0.5 & & \\
\hline $\mathrm{C} 3$ & $40^{\circ} 29^{\prime} 33.7^{\prime \prime} \mathrm{N}-27^{\circ} 57^{\prime} 52.9^{\prime \prime} \mathrm{E}$ & 0.5 & & \\
\hline C4 & $40^{\circ} 30^{\prime} 24.1^{\prime \prime} \mathrm{N}-27^{\circ} 47^{\prime} 30.9^{\prime \prime} \mathrm{E}$ & 0.5 & & \\
\hline $\mathrm{C} 5$ & $40^{\circ} 29^{\prime} 38.9^{\prime \prime} \mathrm{N}-27^{\circ} 40^{\prime} 59.5^{\prime \prime} \mathrm{E}$ & 0.5 & & \\
\hline C6 & $40^{\circ} 26^{\prime} 04.0^{\prime \prime} \mathrm{N}-27^{\circ} 44^{\prime} 53.3^{\prime \prime} \mathrm{E}$ & 0.5 & & \\
\hline
\end{tabular}


October 2011, and January 2012 (Figure 1). The coordinates for each sampling site were determined using a hand-held GPS. Coordinates and other characteristics of each sampling site are given in Table 1.

The Ostracoda samples were collected with a hand net (mesh size $50 \mu \mathrm{m}$ ) from six stations (from shallow waters not exceeding $50 \mathrm{~cm}$ in depth) which has $0.1 \mathrm{~m} 2$ sampling area. For other stations, a Van Veen Grab sampler was used to perform vertical cross-section sampling at depths of $1,5,10,20$, and $30 \mathrm{~m}$ which has $0.1 \mathrm{~m} 2$ sampling field. Two replicates were collected in each station. The $200 \mathrm{gr}$ of the uppermost sediments was fixed in $70 \%$ ethanol in situ. Also 200 gr sediments were gathered and stored for the sediment analysis. For distinguish the ostracod species, the sediment was washed off under pressurized tap water and separated into four grain-size fractions by using standardized sieves $(2,1.5,0.5,0.25$, and $0.125 \mathrm{~mm}$ mesh size). Ostracods were sorted under a stereomicroscope and fixed again in $70 \%$ ethanol. Subsequently, the washed specimens were preserved in $70 \%$ ethanol, and the retained material transferred to a petri dish to be picked out of the sediment under a stereo zoom microscope, and the soft body parts were dissected in lactophenol solution for taxonomic identification. The number of adult individuals belonging to each identified ostracod species was detected. The ostracods were handpicked and identified using the keys developed by Mordukhai and Boltovskoi (1969) [26], Schornikov (1969) [27], Barbeito-Gonzales (1971) [28], Hartmann and Puri (1974) [29], Bonaduce et al. (1975) [30], Athersuch et al. (1989) [31], Yassini (1979) [32], and Stambolidis (1985) [33]. The current taxonomy and classification of ostracod species were checked using the WoRMS (2018) [34] (http://www.marinespecies.org/aphia.php? $p=$ taxdetails\&id=1078).

\section{Analytical Procedure}

The sea water was collected by $3 \mathrm{~L}$ Ruttner water sampler with marked rope at $5 \mathrm{~m}$ intervals from five different depths $(1,5,10,20$ and $30 \mathrm{~m})$ for the physico-chemical analyses. The sea temperature $\left({ }^{\circ} \mathrm{C}\right)$ at the water sampling depth was measured by means of a thermometer fixed to the Ruttner water sampler. The Winkler method [35] was used to measure dissolved oxygen (DO) (mgL $\left.{ }^{1}\right)$ and the Mohr-Knudsen method [36] for the salinity (Sal.) (\%o). The Orion multiparameter device was used to measure the $\mathrm{pH}$ and ORP value of the seawater in situ. The transparency of the water was determined by using a $25 \mathrm{~cm}$ diameter Secchi disc. Mud percentage analyses of the sediments were defined according to Folk (1974) [37] methods and classification, sand fraction is composed by grains whose diameter varies from 63 to 2000 $\mathrm{mm}$, silt fraction consists of grains with diameter ranging between 4 and $63 \mathrm{~mm}$, and clay fraction constitutes very fine material, whose diameter is less than $4 \mathrm{~mm}$. Total organic carbon (TOC) was analyzed using the Walkey-Blake method, which involves titration after a wet combustion of the samples $[38,39]$. The total calcium carbonate contents of the sediments were determined using the gasometric-volumetric method [39].

\section{Statistical Analyses}

Bray-Curtis similarity index was used to detect the species similarity among the 21 sampling stations. The degree of similarities were expressed as dendrograms. Bray-Curtis similarity index were estimated using Biodiversity Pro software package 2.0 [40]. Also this software package was used to examine seasonal distributional differences in ostracod species and to calculate the Shannon-Weaver diversity index $\left(\mathrm{H}^{\prime}\right)$ Pielou's evenness $\left(J^{\prime}\right)$ and Margalef richness ( $\left.D^{\prime}\right)$ for each site across four seasons. [40]. These calculation indexes were based on the 36 ostracod species found at the sites.

The frequency of ostracod species was calculated by

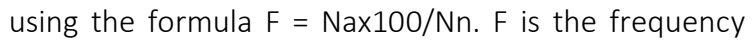
of the species, $\mathrm{Na}$ is the number of sampling stations containing the species, and $\mathrm{Nn}$ is the total number of sampling stations $[41,42]$.

The two-tailed Spearman rank correlation test [43] was applied to evaluate the levels of correlations between the environmental variables (temperature, salinity, $\mathrm{pH}$, dissolved oxygen, total organic carbon, total calcium carbonate, transparency of the water, oxidation-reduction potential, and depth), and 36 ostracod species.

Canonical correspondence analysis (CCA) was also used to evaluate the species-environment relationships and to identify environmental factors potentially influencing ostracod assemblages [44]. Data were analyzed using the Multi-Variate Statistical Package (MVSP), version 3.22 [45]. 


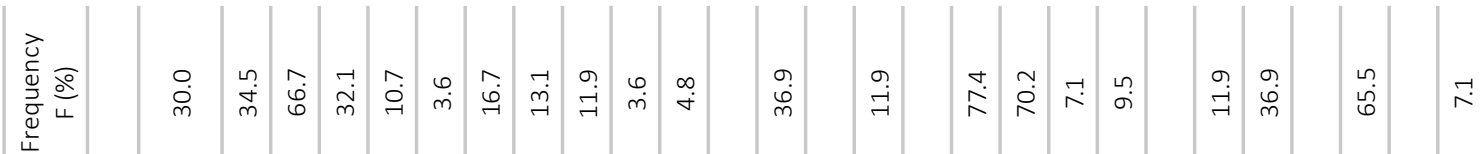

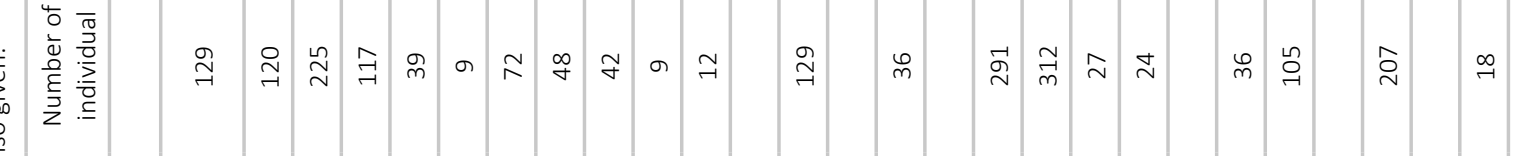
뜨

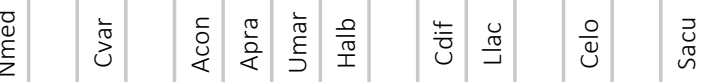

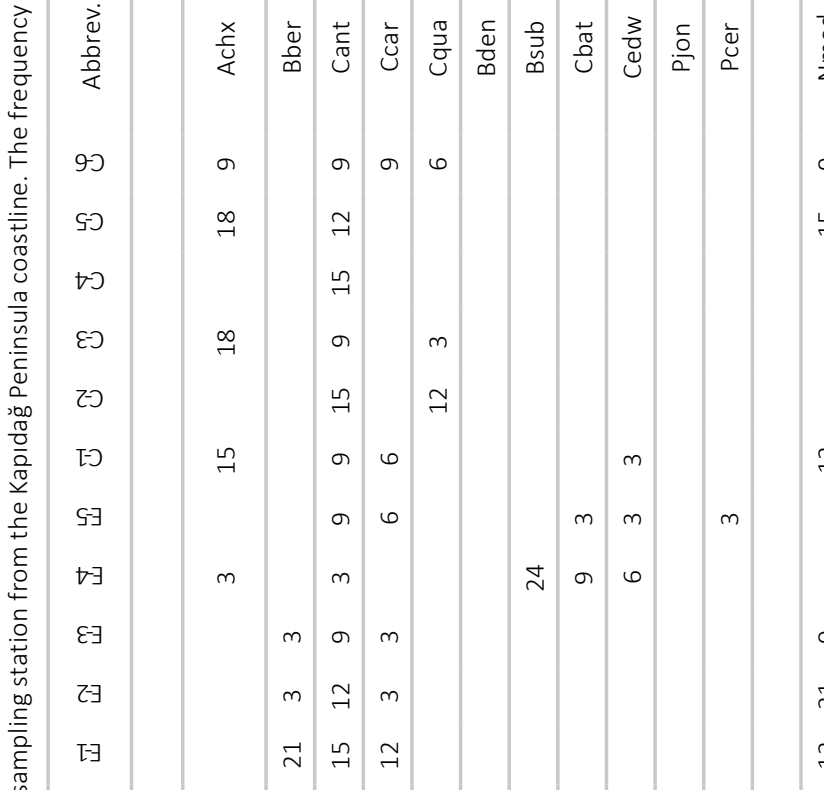

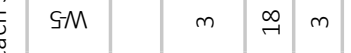

$\vec{\sim} \stackrel{\infty}{\rightarrow}$

$\stackrel{\infty}{\rightarrow} \underset{\sim}{\infty}$

$\stackrel{\infty}{\rightarrow}$ 뉴

$\stackrel{\infty}{\rightarrow} \stackrel{m}{m}$

ㄴำ

$$
\stackrel{\infty}{\rightarrow} \stackrel{\sim}{\neg} \underset{\sim}{\neg} \mathrm{m}
$$

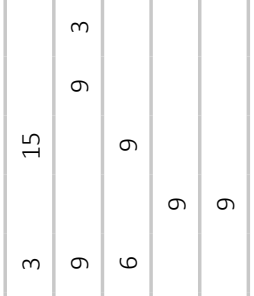

の 6 $\stackrel{7}{*}$

a

$\approx$

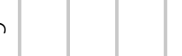

ป

o $\sigma$

a $\sigma$

$\underset{-1}{\sim}$

a $\sigma$

- $\sigma$

든 늠

a $\vec{\sim} \stackrel{\infty}{\sim}$

늠 $\sigma \stackrel{2}{\circ}$

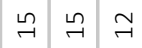

ㄱำ

$\stackrel{n}{\sim}$

$\stackrel{1}{\sim}$

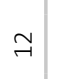

$\begin{array}{lll}0 & 0 & 0\end{array}$

$\stackrel{\infty}{\rightarrow} \stackrel{\infty}{\sim}$

뉴

ㄱำ

늠

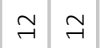

a 6 가

6

6

a $\stackrel{\infty}{\rightarrow}$

$m a)$

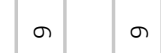

$\stackrel{n}{\sim} \quad 0$
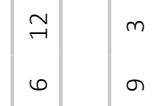

a

a $\sigma \stackrel{\infty}{\rightarrow}$

a $\sigma$

$\stackrel{\infty}{\rightarrow} \quad 0$

a $m$

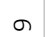

$\stackrel{n}{\sim}$

$a$

$a$

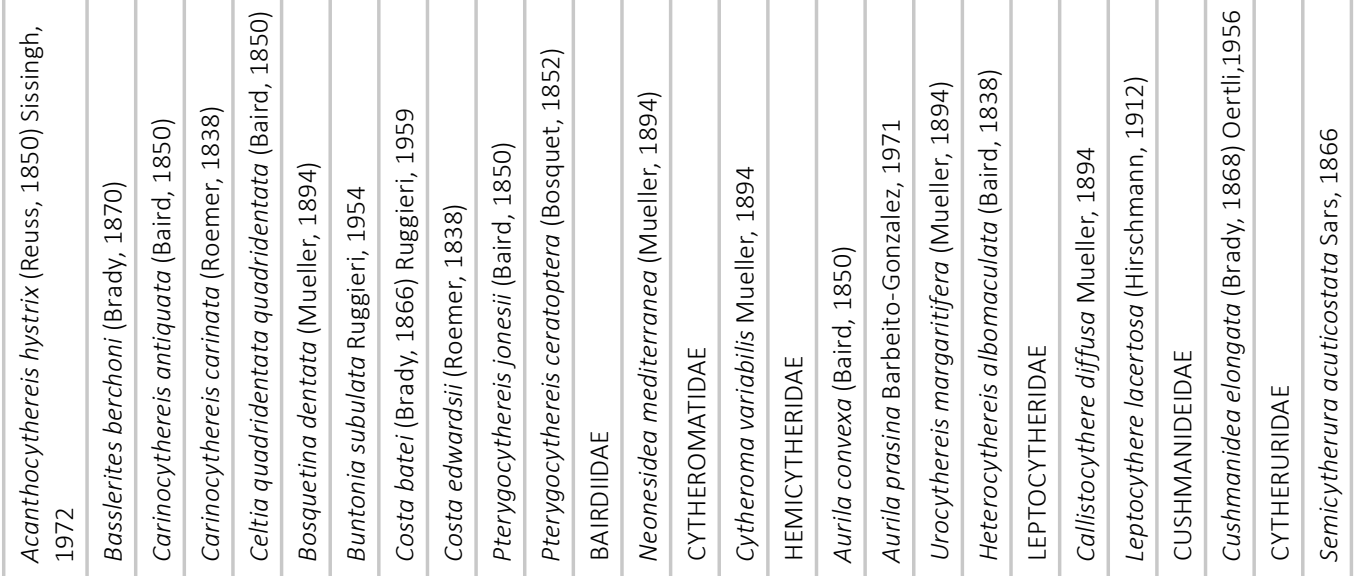




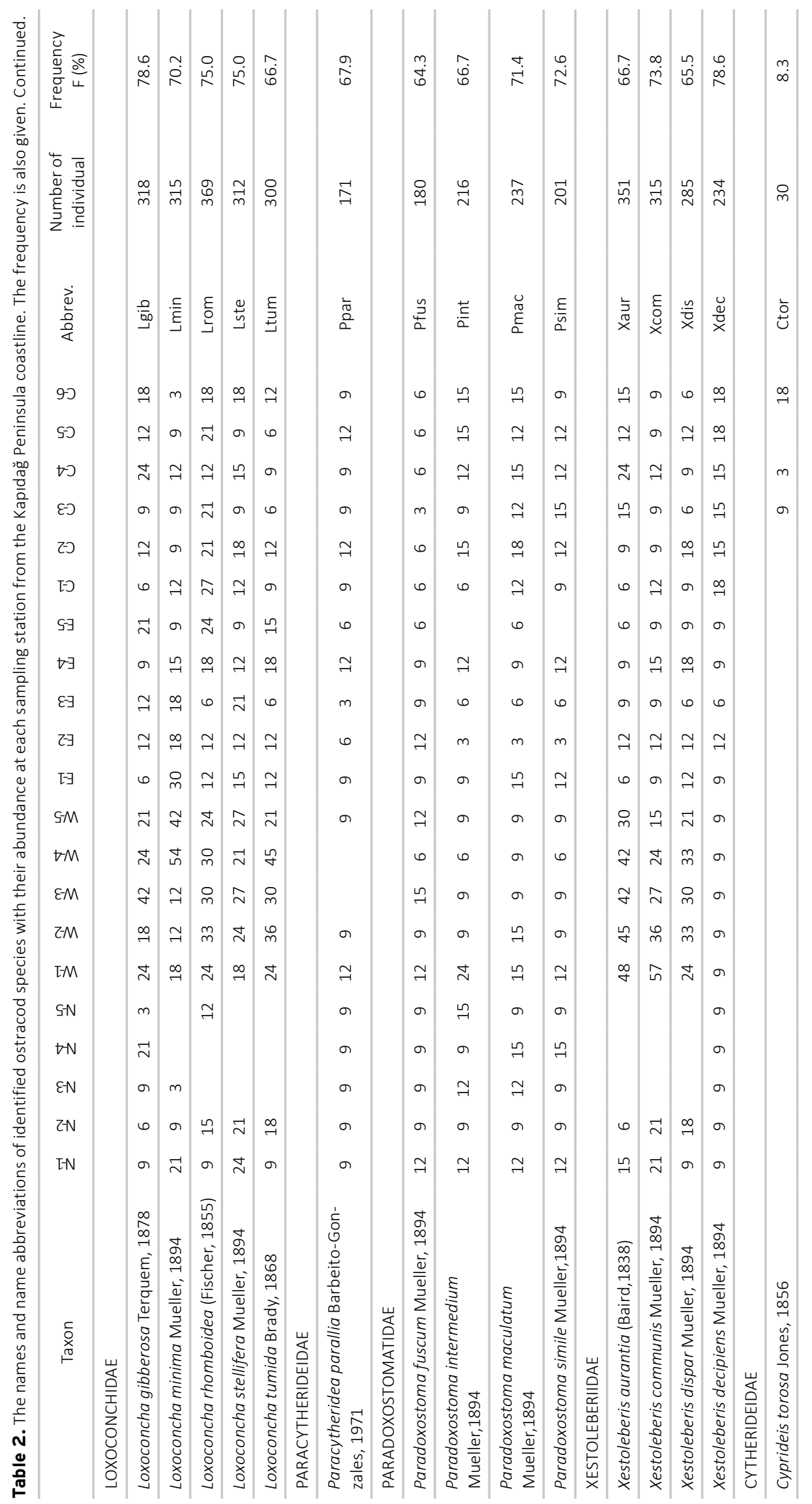




\section{RESULTS}

\section{Species Assemblages}

In this study, 36 ostracod species belonging to $12 \mathrm{fa}$ milies were determined from the 21 stations sampled over the four seasons (Table 2). A total of 5841 individuals were counted. The highest number of individuals observed were: L. rhomboidea (Fischer, 1855) (369 individuals) and $X$. aurantia (Baird, 1838) (351 individuals) species. The greatest numbers of species and individuals were observed from the genera of Loxoconcha (5 species and 1614 individuals), Xestoleberis (4 species and 1185 individuals), and Paradoxostoma (4 species and 834 individuals).

Carinocythereis antiquata, A. convexa, L. gibberosa, $P$. fuscum, $P$. maculatum, $C$. elongata, and $X$. decipiens were the most distributed species on the Kapıdağ Peninsula coastline (see Table 2). The most frequent species were L. gibbereosa (78.6\%), X. decipiens (78.6\%), and A. convexa $(77.4 \%)$; the least frequent species were B. dentata (3.6\%), P. jonesii (3.6\%), and P. ceratoptera (4.8\%) (see Table 2).

\section{Water Quality}

During the study, water temperature varied between $7.5^{\circ} \mathrm{C}$ and $30^{\circ} \mathrm{C}$, salinity varied between 12.5 and 29.2 $\%$, $\mathrm{pH}$ varied between 6.6 and 8.7, ORP varied between -104.1 and 672.3 and DO varied between 1.2 and 15.3 $\mathrm{mg} \mathrm{L}^{-1}$. Total organic carbon content of the sediment varied between $0.02 \%$ and $3.5 \%$, total calcium carbonate varied between $0.3 \%$ and $85.9 \%$, and mud percentages were highest in the deeper stations compared with the coastal sampling stations (Table 3 ).

\section{Species Tolerance and Environment Correlation}

Species such as L. rhomboidea, L. stellifera, L. tumida, L. minima, $X$. aurantia, $X$. communis, and $A$. prasina are dominant species because these species are highly tolerant to various ecological variables (see Table 3). Some habitat variables and ostracod species observed on the coastline of Kapıdağ Peninsula are shown in Table 3.

According to the Shannon-Weaver diversity index values, the highest species diversity was determined at sampling stations $\mathrm{W}-2$ and $\mathrm{W}-3$ in spring and the lowest in fall at the sampling station $\mathrm{N}-4$. Pielou's evenness ( $\mathrm{J}$ ') results were highest at sampling stations $\mathrm{N}-3, \mathrm{~N}-4$, and
E-4 in fall, E-3, E-4, E-5, and C-5 in winter, and were the lowest at the sampling station E-3 in spring. According to Margalef richness ( $D^{\prime}$ ) results, the highest value was determined at sampling station N-4 in fall, while the lowest value was at station $\mathrm{W}-3$ in summer (Table 4).

Bray-Curtis similarity index illustrates eight clustering groups of species (Figure 3 A). Groups 7 and 8 have subclusters grouped by similarity of ostracod assemblages. Most ostracods determined in this study have been found in the continental shelf of the Sea of Marmara. Therefore most of them are high tolerant and abundant species and they grouped together with in the seventh clustering group (Table 3). Bray-Curtis similarity index illustrates five clustering groups of stations (Figure 3 B). The level of similarity among station with a cluster is highly related to habitat type and depth as seen in Figure 3 B (Table 1). Because C-1, C-2, C-3, C-4, C-5 , C-6 are coastal stations and grouped together with. Also $\mathrm{W}-1$, W-2, W-3, W-4, W-5 stations grouped together with in the west side of the Kapıdağ peninsula.

The significant correlations among the 36 species and 10 environmental variables according to the results of the Spearman correlation analysis are shown in Table 5. Depth, mud percentage, and transparency of the water were the most effective ecological parameters on the ostracod species according to Spearman correlations on the Kapıdağ Peninsula coastline.

While there was no significant relationship between the number of species and physicochemical parameters at the stations, a positive correlation was found between the number of individuals and total calcium carbonate and species numbers (Table 6).

The relationship between the physicochemical variables and species composition on the Kapıdağ Peninsula coastline is illustrated by the CCA biplot in Figure 4 The lengths of the arrows on the CCA graph show the strong effect of environmental variables on the distribution of ostracods (Figure 4). According to the results of the CCA, mud percentage and TCC content were the factors most affecting ostracod species on the Kapıdağ Peninsula coastline. Also species composed groups coherent with Bray-Curtis dendrograms (Figure 3) that shown with dashes in Figure 4. 
Table 3. Determined environmental variables in habitats of living ostracod species on the coasts of Kapıdağ Peninsula. (Abbreviations: $\mathrm{Sal}=$ salinity, $\mathrm{DO}=$ dissolved oxygen; $\mathrm{T}=$ temperature; $\mathrm{TOC}=$ total organic carbon; $\mathrm{TCC}=$ total calcium carbonate; $\mathrm{ORP}=$ oxidation-reduction potential; $\mathrm{SD}=$ Secchi depth; $\mathrm{MP}=$ mud percentage; $\mathrm{TNI}=$ total number of individuals $)$.

\begin{tabular}{|c|c|c|c|c|c|c|c|c|c|c|c|}
\hline $\begin{array}{l}\text { Species } \\
\text { Code }\end{array}$ & $\begin{array}{l}\text { Depth } \\
\text { (m) }\end{array}$ & Sal. (\%о) & $\begin{array}{c}\mathrm{DO} \\
\left(\mathrm{mgL}^{-1}\right)\end{array}$ & $\mathrm{pH}$ & $\mathrm{T}\left({ }^{\circ} \mathrm{C}\right)$ & TOC (\%) & TCC (\%) & MP (\%) & ORP & $\mathrm{SD}(\mathrm{m})$ & TNI \\
\hline Achx & $0-30$ & $17.7-27.9$ & $1.2-14.6$ & $7.4-8.7$ & $7.5-27$ & $\begin{array}{l}0.29- \\
2.41\end{array}$ & $\begin{array}{r}0.7- \\
85.85\end{array}$ & $0.3-70.8$ & $(-85) ; 610.3$ & $0.5-10.5$ & 129 \\
\hline Acon & $0-30$ & $\begin{array}{l}12.5- \\
29.2\end{array}$ & $1.2-14.7$ & $6.6-8.7$ & $7.5-30$ & $\begin{array}{l}0.02- \\
2.89\end{array}$ & $\begin{array}{r}0.3- \\
85.85\end{array}$ & $0.3-94.2$ & $(-104.1) ; 672.3$ & $0.5-13$ & 291 \\
\hline Apra & $0-30$ & $\begin{array}{l}12.5- \\
29.2\end{array}$ & $1.2-14.7$ & $6.6-8.7$ & $7.5-30$ & $\begin{array}{l}0.02- \\
2.89\end{array}$ & $\begin{array}{r}0.3- \\
85.85\end{array}$ & $0.3-94.2$ & $(-85) ; 672.3$ & $0.5-12$ & 312 \\
\hline Bber & $1-30$ & $\begin{array}{l}17.1- \\
28.2\end{array}$ & $1.2-15.3$ & $6.6-8.7$ & $7.5-27$ & $0.02-3.5$ & $0.7-85.9$ & $2.4-74.1$ & $(-85) ; 623.6$ & $1-11.0$ & 120 \\
\hline Bden & $5-10$ & $19-24.7$ & $1.6-14.3$ & $7.6-8.2$ & $7.5-16.5$ & $0.52-2.1$ & $4.6-22.1$ & $\begin{array}{l}10.6- \\
13.4\end{array}$ & $35.4 ; 610.3$ & $2.7-10.0$ & 9 \\
\hline Bsub & $1-30$ & $19-27.5$ & $1.2-14.3$ & $7.4-8.2$ & $8.0-17.0$ & $\begin{array}{l}0.59- \\
2.89\end{array}$ & $0.4-22.1$ & $2.2-70.8$ & $(-85) ; 610.6$ & $1.0-12.0$ & 72 \\
\hline Cant & $0-30$ & $\begin{array}{l}12.7- \\
29.2\end{array}$ & $1.2-15.3$ & $6.6-8.7$ & $7.5-27$ & $\begin{array}{l}0.02- \\
2.41\end{array}$ & $0.3-85.9$ & $0.3-94.2$ & $(-85) ; 672.3$ & $0.5-12.0$ & 225 \\
\hline Cbat & $1-30$ & $\begin{array}{l}17.7- \\
29.2\end{array}$ & $2.0-9.9$ & $7.4-8.2$ & $8.0-18.0$ & $0.5-2.1$ & $0.7-22.1$ & $2.4-94.2$ & $(-38.4) ; 364.8$ & $1.0-12.0$ & 48 \\
\hline Ccar & $0-30$ & $\begin{array}{l}17.7- \\
29.2\end{array}$ & $1.2-15.3$ & $6.6-8.7$ & $7.5-27$ & $0.02-2.3$ & $\begin{array}{r}0.3- \\
85.85\end{array}$ & $0.4-94.2$ & $(-84.3) ; 599.5$ & $0.5-12.0$ & 117 \\
\hline Cdif & $0-30$ & $\begin{array}{l}16.8- \\
25.9\end{array}$ & $2.0-13.2$ & $7.2-8.7$ & $8.0-27.0$ & $0.5-2.1$ & $0.3-22.1$ & $0.4-94.2$ & $54.5-592$ & $0.5-10$ & 36 \\
\hline Cedw & $0-30$ & $\begin{array}{l}21.2- \\
25.9\end{array}$ & $2.0-10.5$ & $7.0-8.2$ & $8.0-27.0$ & $0.47-2.1$ & $\begin{array}{r}0.3- \\
17.98\end{array}$ & $0.4-94.2$ & $54.5-672.3$ & $0.5-10$ & 42 \\
\hline Celo & $0-30$ & $\begin{array}{l}12.5- \\
29.2\end{array}$ & $1.2-14.6$ & $6.6-8.7$ & $7.5-30.0$ & $\begin{array}{l}0.02- \\
2.89\end{array}$ & $0.3-85.9$ & $0.3-94.2$ & $(-85) ; 672.3$ & $0.5-12$ & 207 \\
\hline Cqua & $0-10$ & $\begin{array}{l}17.7- \\
25.4\end{array}$ & $2.0-13.2$ & $7.6-8.7$ & $8.0-28.0$ & $0.29-2.1$ & $0.6-22.1$ & $0.3-13.4$ & $54.5-413.1$ & $0.5-10$ & 39 \\
\hline Ctor & $0-20$ & $\begin{array}{l}12.5- \\
25.4\end{array}$ & $1.3-13.2$ & $7.4-8.7$ & $10.7-29$ & $0.06-1.7$ & $0.6-5.8$ & $0.3-0.6$ & $50-643.3$ & 0.50 & 30 \\
\hline Cvar & $10-20$ & $18.3-25$ & $1.2-14.3$ & $7.6-8.2$ & $7.7-27$ & $0.64-2.1$ & $0.4-85.9$ & $0.9-13.4$ & $(-40.6) ; 389.4$ & $2.7-10.5$ & 36 \\
\hline Halb & $0-1$ & $\begin{array}{l}12.5- \\
23.7\end{array}$ & $2.7-15.3$ & $7-8.5$ & $7.5-27$ & $0.02-1.7$ & $1.2-4.06$ & $0.4-58.3$ & $62.3-620.9$ & $0.5-1$ & 24 \\
\hline Lgib & $0-30$ & $\begin{array}{l}12.5- \\
28.4\end{array}$ & $1.2-15.3$ & 7.1-8.7 & $7.5-30$ & $0.02-3.5$ & $0.3-85.9$ & $0.3-94.2$ & $(-104.1) ; 643.3$ & $0.5-13$ & 318 \\
\hline Llac & $0-30$ & $\begin{array}{l}17.1- \\
28.4\end{array}$ & $1.2-15.3$ & $7.0-8.7$ & $7.5-27$ & $0.42-3.5$ & $\begin{array}{c}0.3- \\
85.85\end{array}$ & $0.3-94.2$ & $(-104.1) ; 610.3$ & $0.5-13$ & 105 \\
\hline Lmin & $0-30$ & $\begin{array}{l}17.1- \\
28.4\end{array}$ & $1.2-15.3$ & $6.6-8.7$ & $7.5-30$ & $0.02-3.5$ & $0.3-85.9$ & $0.3-94.2$ & $(-85) ; 623.6$ & $0.5-12$ & 315 \\
\hline Lrom & $0-30$ & $\begin{array}{l}12.7- \\
29.2\end{array}$ & $1.2-15.3$ & $6.6-8.7$ & $7.5-30$ & $0.02-3.5$ & $0.3-85.9$ & $0.3-94.2$ & $(-104.1) ; 623.6$ & $0.5-13$ & 369 \\
\hline Lste & $0-30$ & $\begin{array}{l}12.7- \\
28.4\end{array}$ & $1.2-15.3$ & $6.6-8.7$ & $7.5-30$ & $0.02-3.5$ & $0.3-85.9$ & $0.3-94.2$ & $(-84.3) ; 672.3$ & $0.5-12$ & 312 \\
\hline Ltum & $0-30$ & $\begin{array}{l}17.1- \\
28.4\end{array}$ & $1.2-15.3$ & $6.6-8.7$ & $7.5-30$ & $0.02-3.5$ & $0.3-85.9$ & $0.3-94.2$ & $(-104.1) ; 672.3$ & $0.5-13$ & 300 \\
\hline Nmed & $0-20$ & $\begin{array}{l}17.1- \\
25.4\end{array}$ & $1.3-15.3$ & $6.6-8.7$ & $7.5-30$ & $\begin{array}{l}0.02- \\
2.89\end{array}$ & $0.3-8.2$ & $0.4-74.1$ & $(-57.6) ; 643.3$ & $0.5-12$ & 129 \\
\hline
\end{tabular}


Table 3. Determined environmental variables in habitats of living ostracod species on the coasts of Kapıdağ Peninsula. (Abbreviations: Sal= salinity, $\mathrm{DO}=$ dissolved oxygen; $\mathrm{T}=$ temperature; $\mathrm{TOC}=$ total organic carbon; $\mathrm{TCC}=$ total calcium carbonate; ORP = oxidation-reduction potential; $\mathrm{SD}=$ Secchi depth; $\mathrm{MP}=$ mud percentage; $\mathrm{TNI}$ = total number of individuals). Continued.

\begin{tabular}{|c|c|c|c|c|c|c|c|c|c|c|c|}
\hline $\begin{array}{c}\text { Species } \\
\text { Code }\end{array}$ & $\begin{array}{l}\text { Depth } \\
\text { (m) }\end{array}$ & Sal. (\%o) & $\begin{array}{c}\mathrm{DO} \\
\left(\mathrm{mgL}^{-1}\right)\end{array}$ & $\mathrm{pH}$ & $\mathrm{T}\left({ }^{\circ} \mathrm{C}\right)$ & TOC (\%) & TCC (\%) & $\mathrm{MP}(\%)$ & ORP & $\mathrm{SD}(\mathrm{m})$ & TNI \\
\hline Pcer & $10-30$ & $\begin{array}{l}18.3- \\
25.9\end{array}$ & $2.0-12.0$ & 7.4-8.1 & $7.7-15$ & $0.76-1.9$ & $0.4-5.22$ & $0.9-94.2$ & $(-40.6) ; 389.4$ & $7.5-10$ & 12 \\
\hline Pfus & $0-30$ & $\begin{array}{l}12.5- \\
29.2\end{array}$ & $1.2-14.7$ & $6.6-8.7$ & $7.5-30$ & $\begin{array}{l}0.02- \\
2.89\end{array}$ & $0.3-85.9$ & $0.3-94.2$ & $(-85) ; 672.3$ & $0.5-12$ & 180 \\
\hline Pint & $0-30$ & $\begin{array}{l}12.7- \\
29.2\end{array}$ & $1.2-14.7$ & $6.6-8.7$ & $7.5-30$ & $\begin{array}{l}0.02- \\
2.89\end{array}$ & $0.3-85.9$ & $0.3-74.1$ & $(-85) ; 672.3$ & $0.5-12$ & 216 \\
\hline Pjon & 10 & $\begin{array}{l}22.6- \\
29.2\end{array}$ & $1.8-12.0$ & $7.6-7.9$ & $9.5-18.0$ & $\begin{array}{l}0.64- \\
1.41\end{array}$ & $0.4-7.31$ & 0.9 & $182.5-599.5$ & $7.5-10$ & 9 \\
\hline Pmac & $0-30$ & $\begin{array}{l}17.5- \\
29.2\end{array}$ & $1.2-14.7$ & $6.6-8.7$ & $7.5-30$ & $\begin{array}{l}0.02- \\
2.89\end{array}$ & $0.3-85.9$ & $0.3-94.2$ & $(-85) ; 672.3$ & $0.5-12$ & 237 \\
\hline Ppar & $0-30$ & $\begin{array}{l}12.5- \\
29.2\end{array}$ & $1.2-14.7$ & $6.6-8.7$ & $7.5-30$ & $\begin{array}{l}0.02- \\
2.89\end{array}$ & $0.3-14.5$ & $0.3-94.2$ & $(-104.1) ; 672.3$ & $0.5-13$ & 171 \\
\hline Psim & $0-30$ & $\begin{array}{l}12.5- \\
29.2\end{array}$ & $1.2-14.7$ & $6.6-8.7$ & $7.5-30$ & $\begin{array}{l}0.02- \\
2.89\end{array}$ & $0.3-85.9$ & $0.3-74.1$ & $(-85) ; 672.3$ & $0.5-12$ & 201 \\
\hline Sacu & $1-30$ & $\begin{array}{l}17.7- \\
25.9\end{array}$ & $1.6-7.3$ & $7.6-8.0$ & $7.5-26.5$ & $0.29-1.3$ & $2.7-8.2$ & $4.3-19.8$ & $62.3-610.3$ & $1-10.5$ & 18 \\
\hline Umar & $5-30$ & $\begin{array}{l}21.9- \\
27.5\end{array}$ & 1.2-9.6 & 7.6-8.1 & $7.5-26$ & $0.7-2.58$ & $2.32-9.3$ & $\begin{array}{l}10.6- \\
70.8\end{array}$ & $(-85.0) ; 610.3$ & $4-10.5$ & 27 \\
\hline Xaur & $0-30$ & $\begin{array}{l}12.5- \\
28.2\end{array}$ & $1.2-15.3$ & $7.0-8.7$ & $7.5-30$ & $0.02-3.5$ & $0.3-85.9$ & $0.3-94.2$ & $(-85) ; 672.3$ & $0.5-10.5$ & 351 \\
\hline Xcom & $0-30$ & $\begin{array}{l}17.1- \\
28.4\end{array}$ & $1.2-15.3$ & $6.6-8.7$ & $7.5-30$ & $0.02-3.5$ & $0.3-85.9$ & $0.3-94.2$ & $(-85) ; 672.3$ & $0.5-12$ & 315 \\
\hline Xdec & $0-30$ & $\begin{array}{l}12.5- \\
29.2\end{array}$ & $1.2-15.3$ & $7.0-8.7$ & $7.5-30$ & $0.02-3.5$ & $0.3-85.9$ & $0.3-94.2$ & $(-104.1) ; 672.3$ & $0.5-13$ & 234 \\
\hline Xdis & $0-30$ & $\begin{array}{l}17.1- \\
28.4\end{array}$ & $1.2-15.3$ & $6.6-8.7$ & $7.5-30$ & $0.02-3.5$ & $0.3-85.9$ & $0.3-94.2$ & $(-104.1) ; 672.3$ & $0.5-13$ & 285 \\
\hline
\end{tabular}

It has been determined that the salinity tolerance ranges of ostracod species on the Kapıdağ Peninsula coastline were between mesohaline to polyhaline. Salinity ranges of the identified ostracod species are shown in Figure 5. Seven ostracod species (B. berchoni, B. dentata, C. diffusa, C. variabilis, P. ceratoptera, P. jonesii, and $U$. margaritifera) were observed only in polyhaline conditions.

\section{DISCUSSION}

The number of ostracod species (36 ostracod species and 5841 individuals) obtained from the Kapıdağ Peninsula coastline was considerably lower than that obtained from Bandırma Bay and Erdek Bay (112 ostracod species and 37550 individuals) [22] (Figure 6). The information obtained from the current study's results indicates that increasing the number of samples will not always provide the expected increase in the number of species and individuals.
The species diversity rate is higher in the spring (26 species) and summer (24 species) seasons compared with the fall (20 species) and winter (20 species) seasons. However, according to the Spearman correlation analysis, no significant relationship was found between the number of species and the ecological parameters. Also, a positive correlation was detected between species of L. gibberosa, B. berchoni, B. dentata, and X. aurantia and the amount of total calcium carbonate (TCC) in sediments. The effect of the TCC was supported by the CCA results as shown in Figure 4. Similarly, a positive correlation has previously been found between species numbers and TCC in studies performed on Bandırma Bay and Erdek Bay $[23,24]$.

In addition to ecological parameters, the distribution of ostracod species is also affected by the composition of vegetation, predation pressure, sediment structure, 


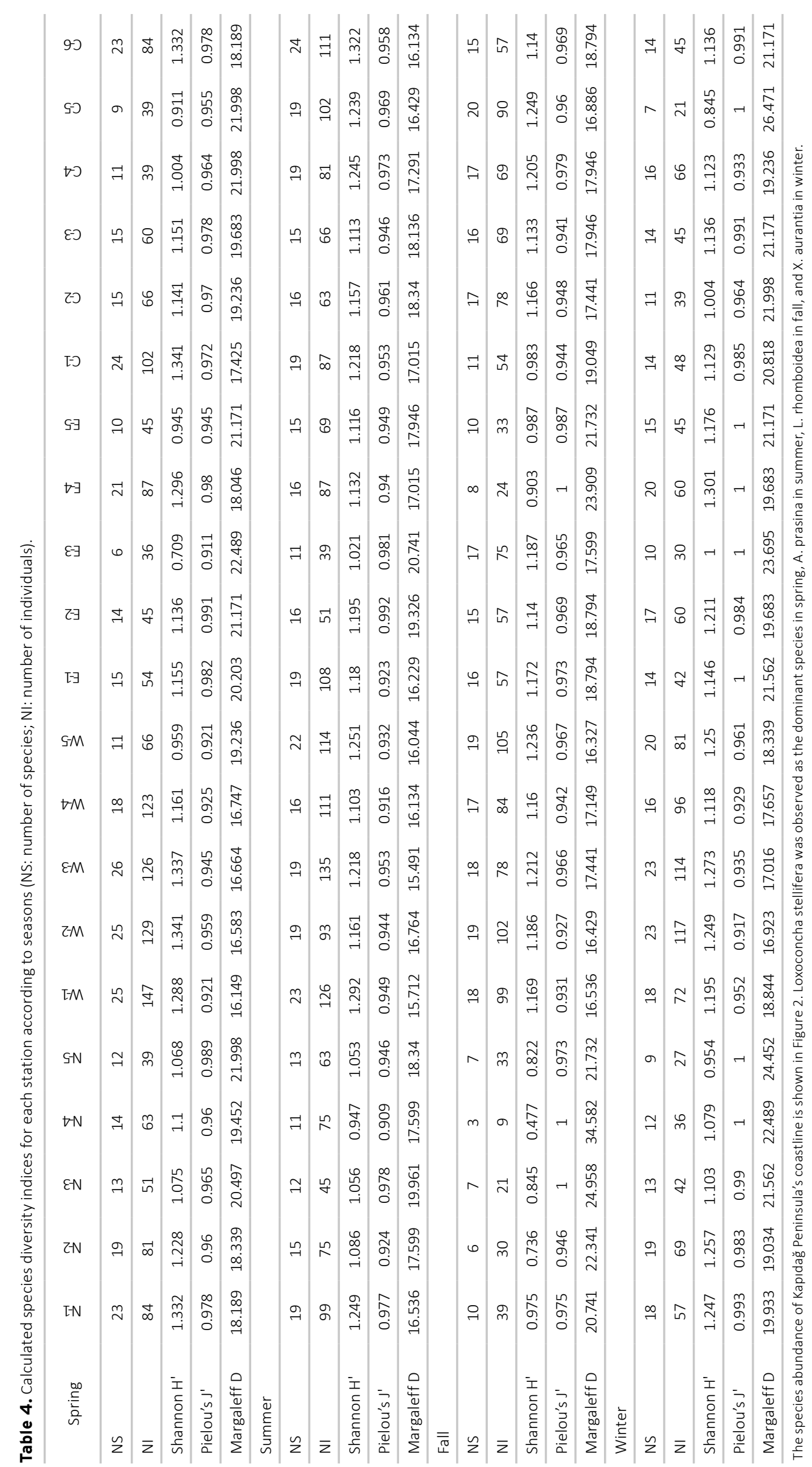




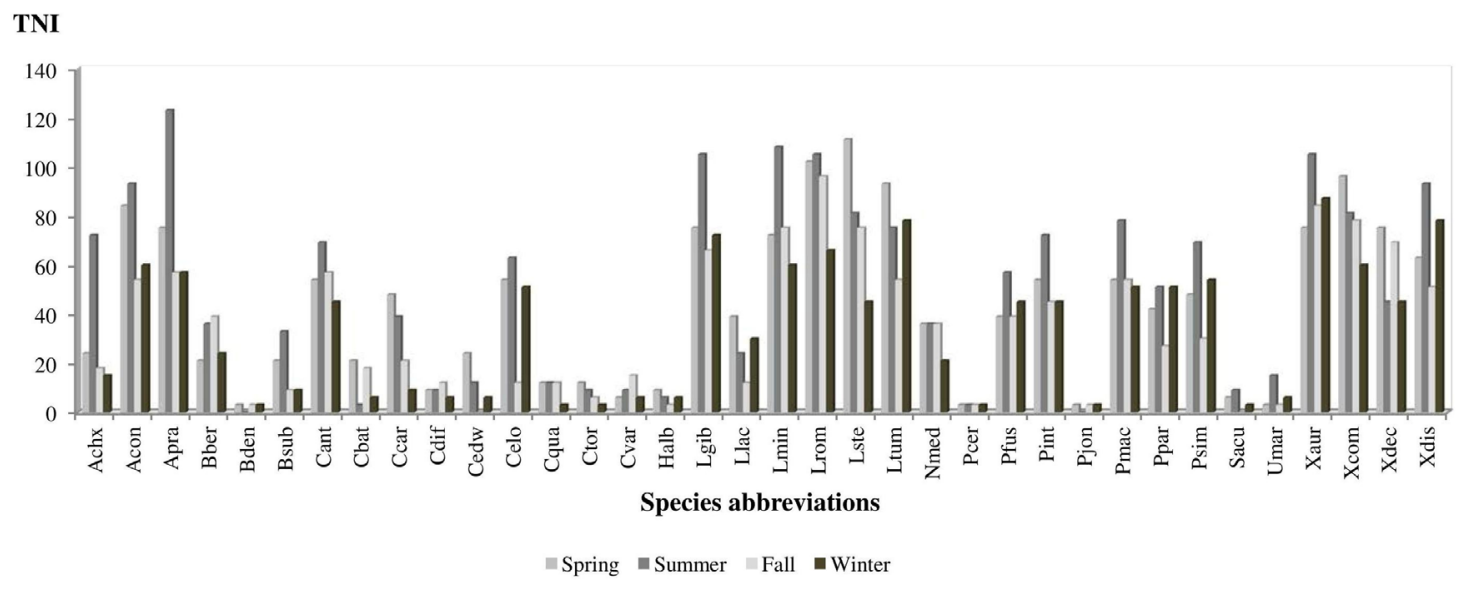

Figure 2. Total number of individuals (TNI) for each species according to season.
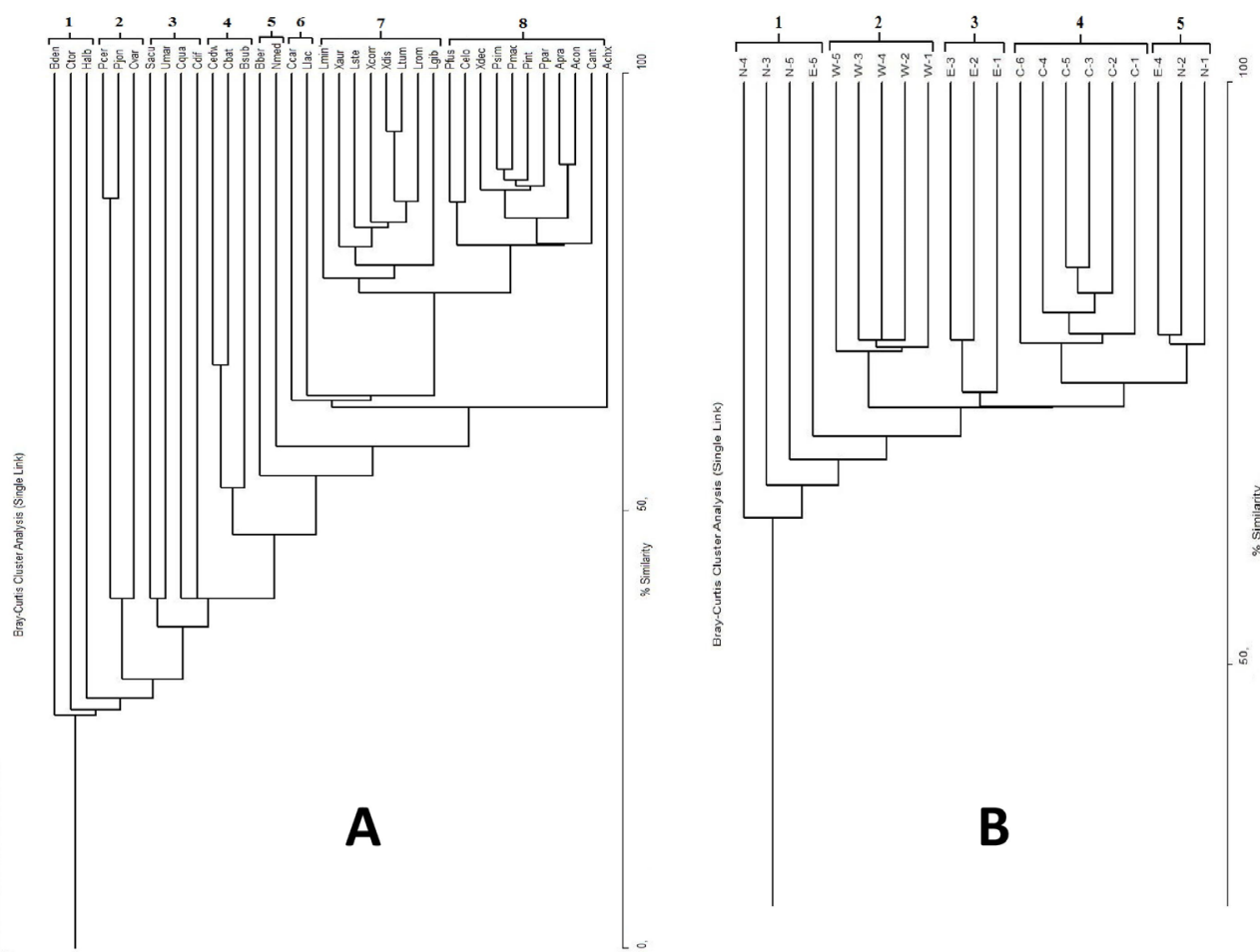

Figure 3. Dendrogram built by Bray-Curtis cluster analysis for the 36 ostracod species determined from 21 sampling stations. A. similarity of ostracod species; B. similarity of stations. 


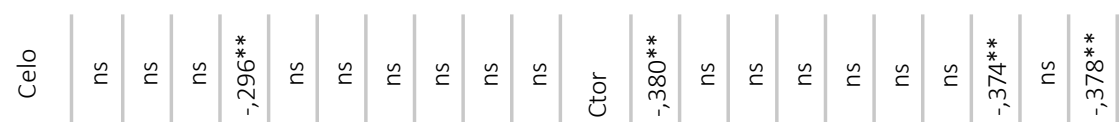

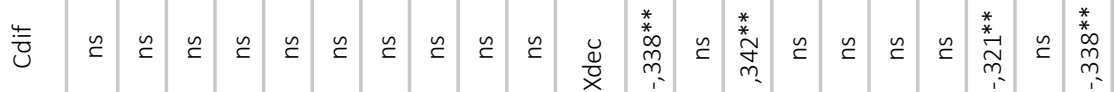

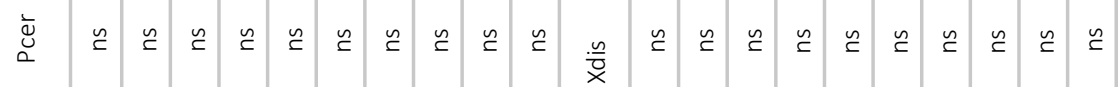

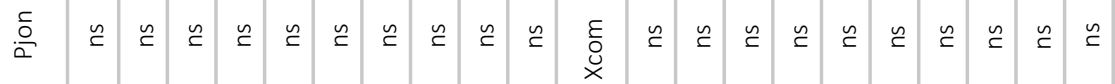

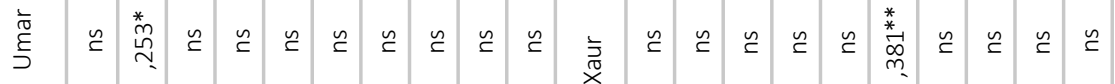

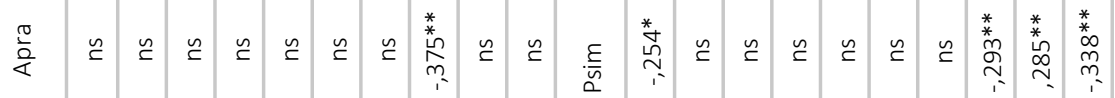

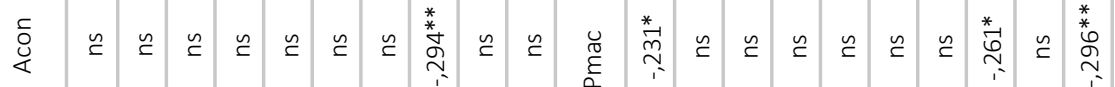

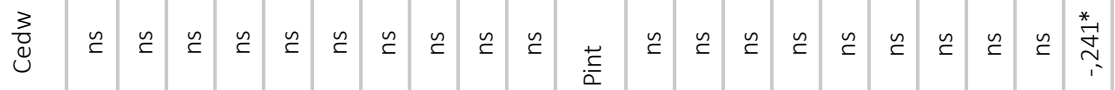

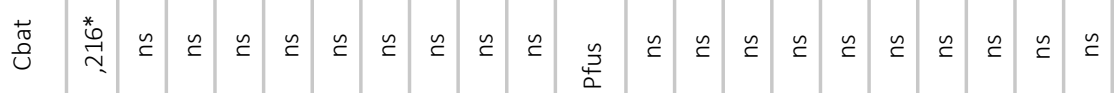

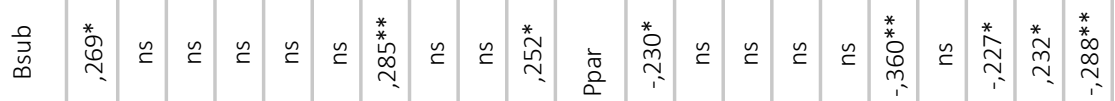

离 苦

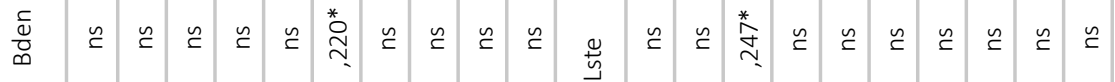

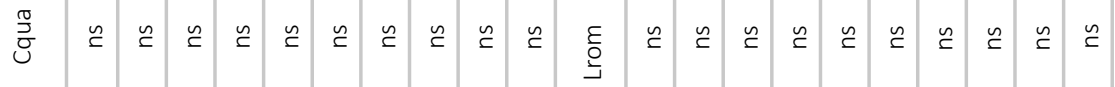

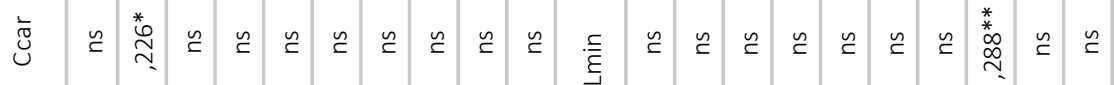

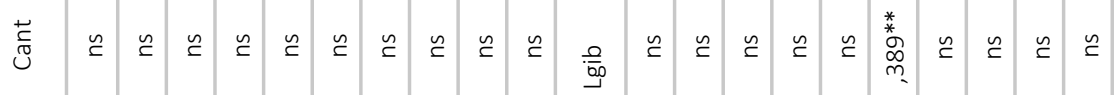

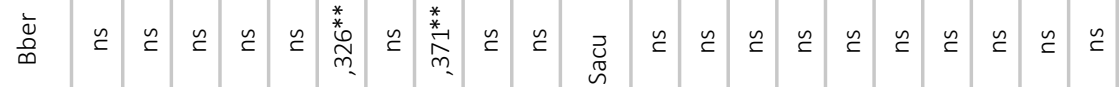

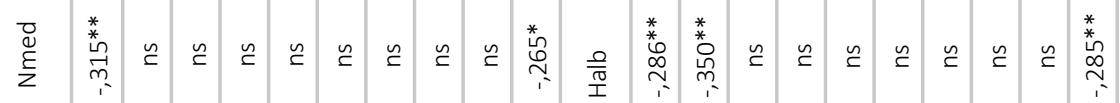

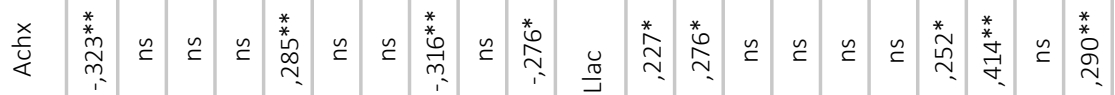

$\stackrel{\infty}{\stackrel{0}{\circ}}$

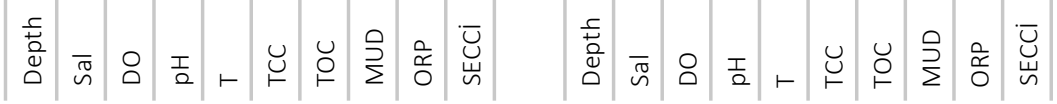


Table 6. Spearman correlation matrix between ecological parameters with number of species and individuals. (Abbreviations are the same as Table 3: NS = number of species; $\mathrm{NI}=$ number of individuals; $\left.{ }^{* *} \mathrm{p}^{<0.01},{ }^{*} \mathrm{p}<0.05\right)$.

\begin{tabular}{|c|c|c|c|c|c|c|c|c|c|c|c|c|}
\hline $\begin{array}{l}\text { Ecological } \\
\text { Parameters }\end{array}$ & Depth & Sal & DO & $\mathrm{pH}$ & T & TCC & TOC & MP & ORP & SD & NS & $\mathrm{NI}$ \\
\hline Depth & 1,000 & & & & & & & & & & & \\
\hline Sal &, $623 * *$ & 1,000 & & & & & & & & & & \\
\hline DO &,$- 226 *$ &,$- 239 *$ & 1,000 & & & & & & & & & \\
\hline $\mathrm{pH}$ & ns & ns & ,616** & 1,000 & & & & & & & & \\
\hline $\mathrm{T}$ & ns & ns & ns & ns & 1,000 & & & & & & & \\
\hline TCC &, $478 * *$ &, $277^{*}$ &,$- 273^{*}$ & ns & ns & 1,000 & & & & & & \\
\hline TOC &, $584^{* *}$ &, $541^{* *}$ & ns & ns &,$- 314 * *$ &, $291^{* *}$ & 1,000 & & & & & \\
\hline MUD &, $776 * *$ &, $492 * *$ & ns & ns & ns &, $370 * *$ &, $434 * *$ & 1,000 & & & & \\
\hline ORP &,$- 274^{*}$ &,- 081 &,$- 477^{* *}$ &,$- 622^{* *}$ &,$- 229 *$ &,$- 229 *$ &,- 055 &,- 147 & 1,000 & & & \\
\hline SD & $924 * *$ &, $554^{* *}$ &,$- 273^{*}$ & ns & ns &, $433 * *$ &, $488 * *$ & ,691** &,$- 256^{*}$ & 1,000 & & \\
\hline NS & ns & ns & ns & ns & ns & ns & ns & ns & ns & ns & 1,000 & \\
\hline
\end{tabular}

chemical material residues in the sediment, and wave motion in the water, as are other living organisms living in the aquatic environment [46]. For this reason, the species diversity may have differed among the different stations due to the influence of the above-mentioned factors.

Aurila convexa, C. antiquata, C. elongata, L. gibberosa, $P$. fuscum, and $X$. decipiens were shown to have a wide distribution in this study. Loxoconcha rhomboidea (369 individuals), X. aurantia (351 individuals) L. gibberosa (318 individuals), L. minima (315 individuals), X. communis (315 individuals), A. prasina (312 individuals), and $L$. stellifera (312 individuals) were the most abundant species on the Kapıdağ Peninsula coastline.

Aurila convexa is known to be a cosmopolitan Mediterranean species [30]. It is also common in the Sea of Marmara and has been recorded in northern parts of the Aegean Sea [33], as well as in the Black Sea in brackish water systems as a polyhaline species [27]. It is widely distributed in the littoral and sublittoral zones of most Turkish coastlines [21]. Aurila convexa was observed at all the stations in the present study at high frequency (77.4\%), with a wide range of ecological parameters and at higher numbers than other species, showing a significant negative correlation with mud percentage.

Aurila prasina is a typical near-shore species and has been reported in a variety of marine habitats in the Aegean Sea, the Black Sea, as well as lagoon environments
[21]. In accordance with other studies, we determined a high number of individuals of this species from 20 stations (excepting E-3 station), in mesohaline to polyhaline conditions at depths ranging from 0.5 to $30 \mathrm{~m}$. Its frequency was $70.2 \%$, and it showed a significant negative correlation with mud percentage, similar to $A$. convexa. Carinocythereis antiquata occurs in all types of bottom sediments, from shallow water to $71 \mathrm{~m}$ depths in the Adriatic Sea [30]. It is also a common species in the Mediterranean Sea [30]. Concordantly, we observed this species at all stations from $0.5 \mathrm{~m}$ to $30 \mathrm{~m}$, in a variety of ecological environments at $66.7 \%$ frequency. No correlation detected between this species and ecological parameters.

Cushmanidea elongata is a common species in the Mediterranean Sea and the Aegean Sea [21]. We observed this species at all stations in mesohaline to polyhaline conditions, although the number of individuals was not high, at $65.5 \%$ frequency. It showed a significant negative correlation with $\mathrm{pH}$.

Loxoconcha gibberosa has been identified in the Aegean Sea and the Sea of Marmara [21]. We determined this species at all the stations on the Kapıdağ Peninsula coastline, from mesohaline to polyhaline salinity conditions, with a high number of individuals and at $78.6 \%$ frequency. A significant positive correction was detected between TCC and this species. 


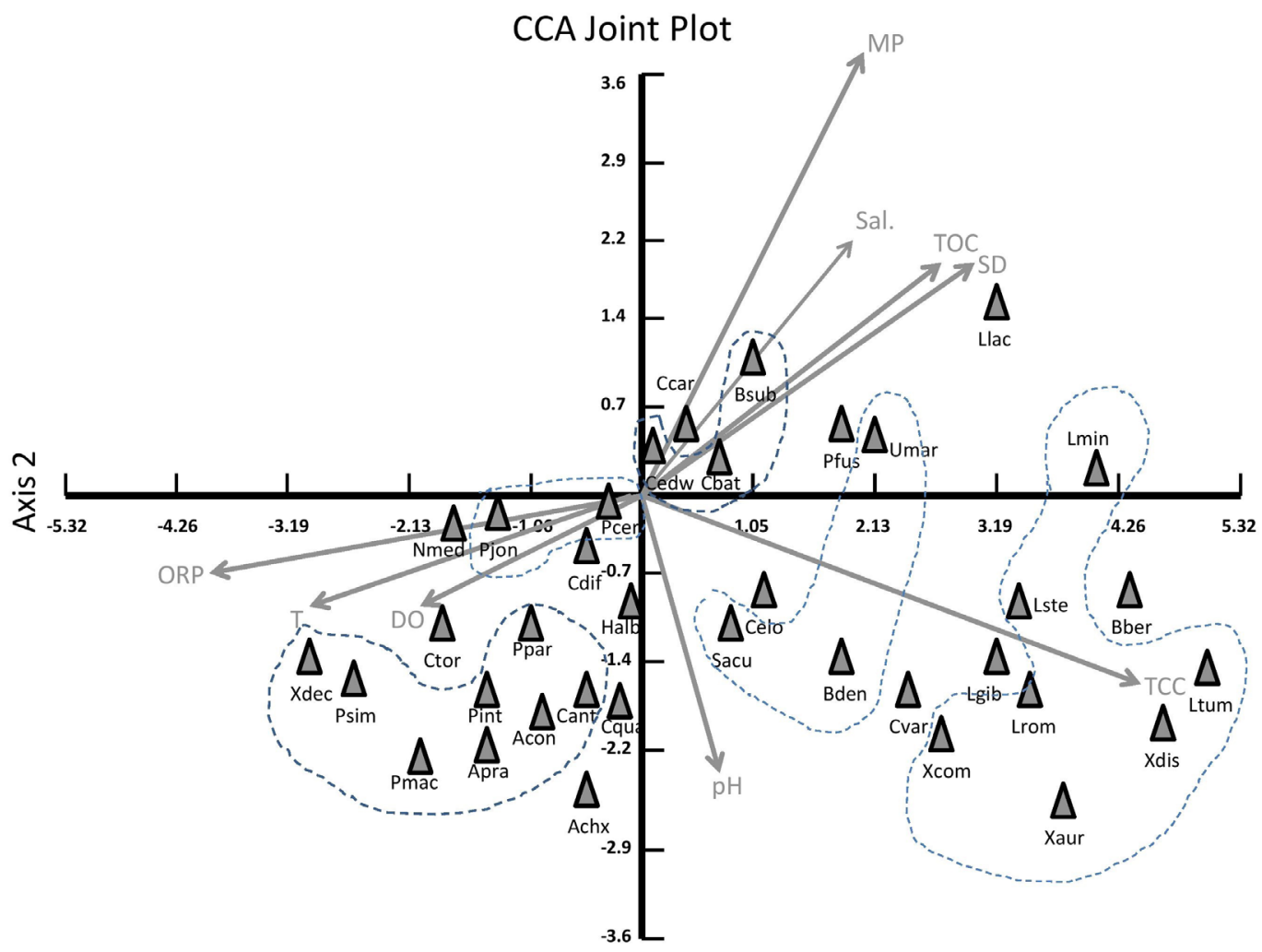

Axis 1

Figure 4. Canonical correspondence analysis (CCA) plot showing relationships between environmental variables and the 36 species. Eigenvalues 0.121-axis 1; 0.089-axis 2; percentage 23.945-axis 1; 17.543-axis 2; Cumulative Percentage 23.945-axis 1; 41.488-axis 2; Cumulative Constr. Percentage 23.945-axis1; 41.488-axis 2; Species-environment correlations 1-axis 1; 1 -axis 2. (The dashes show the species groups that composed compatible with Bray-Curtis dendrograms)

Loxoconcha minima prefer a near-shore environment with sandy, silt, and pelite substrates [30]. We observed this species abundantly at 19 stations (excepting $\mathrm{N}-4$ and $\mathrm{N}-5$ ) at a frequency of $70.2 \%$ (Table 2). It has previously been identified on the coasts of the Mediterranean Sea and the Sea of Marmara [21]. This species showed a significant positive correlation with mud percentage. Xestoleberis aurantia has been found as a euryhaline species in northeast England [46]. This species is known as a marine brackish littoral species, but has also been reported in freshwater and oligohaline shallow-water environments [47]. We observed $X$. aurantia from mesohaline to polyhaline environments at 18 stations. It was observed in the present study with a wide range of ecological parameters at high numbers, at a frequency of $66.7 \%$. A positive correlation was detected with TCC. Xestoleberis communis was observed at 18 stations (excepting $\mathrm{N}-3, \mathrm{~N}-4, \mathrm{~N}-5$ ) with a wide range of ecological parameters but particularly in polyhaline conditions, and at a frequency of $73.8 \%$. This species has been iden- tified as a dominant species and is widely distributed in the Mediterranean Sea $[28,48]$. No correlation was detected between this species and the studied ecological parameters.

We determined $X$. decipiens at all the stations in mesohaline to polyhaline conditions. The number of individuals was not high but the species was widely distributed in different ecological environments at a frequency of 78.6\%. It has been identified on most Turkish coastlines in recent studies [21]. This species showed negative correlations with depth, mud percentage, and Secchi depth, and a positive correlation with dissolved oxygen. Loxoconcha rhomboidea was observed as the most abundant species on the Kapıdağ Peninsula coastline, with the highest individual numbers and at a frequency of $75.0 \%$. It was found in mesohaline to polyhaline conditions at 19 stations (excepting $\mathrm{N}-3$ and $\mathrm{N}-4$ ). This is a very common species, widely found in littoral and sublittoral zones of most Turkish coasts [21]. It has been reported at 1-57 $\mathrm{m}$ depths in the Mediterranean Sea 


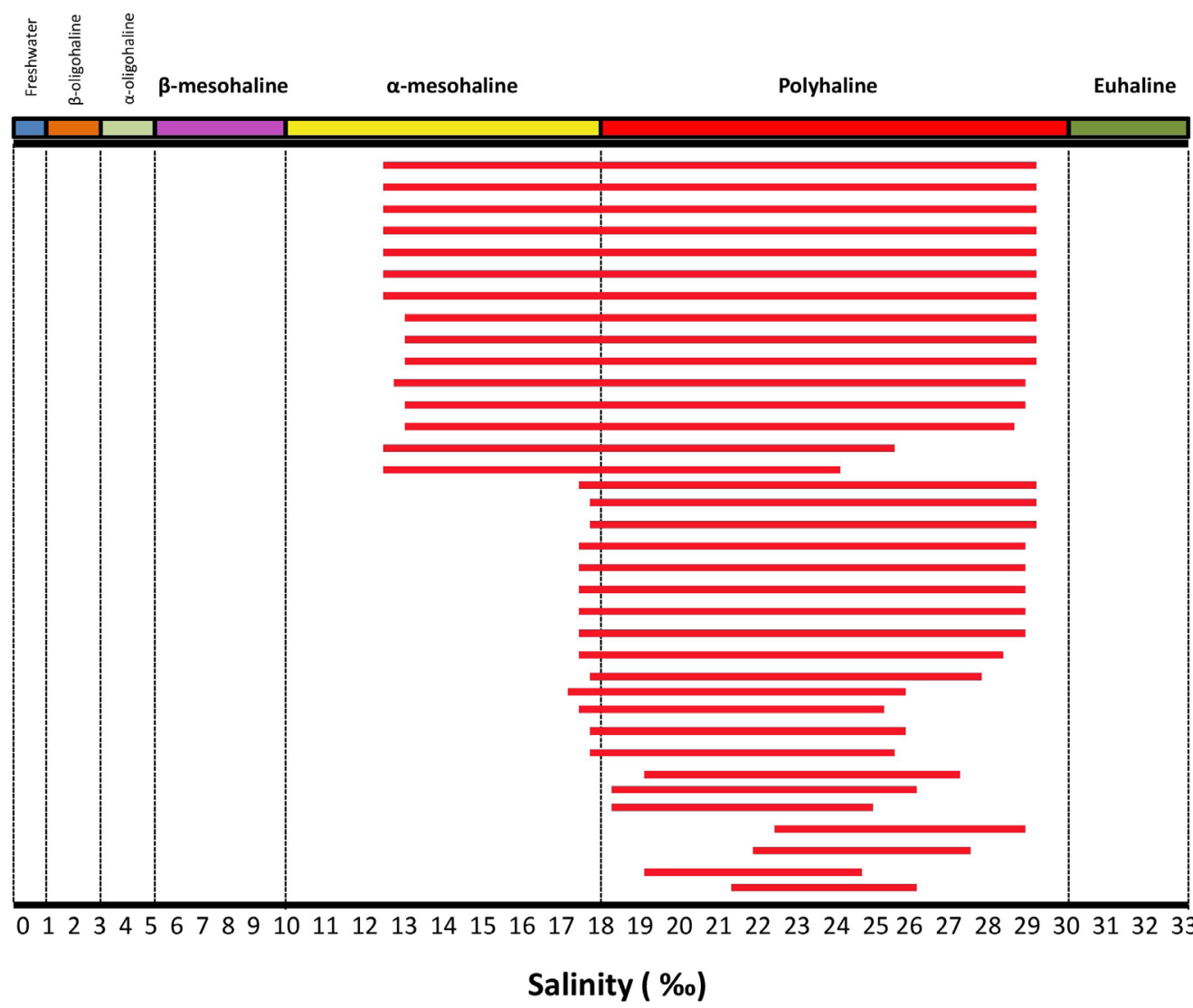

Species Code

Acon

Apra

Celo

Pfus

Ppar

$\mathrm{Xdec}$

Cant

Lrom

\section{Salinity ( \%o)}

Figure 5. The ostracod species and their salinity records from Kapıdağ Peninsula.
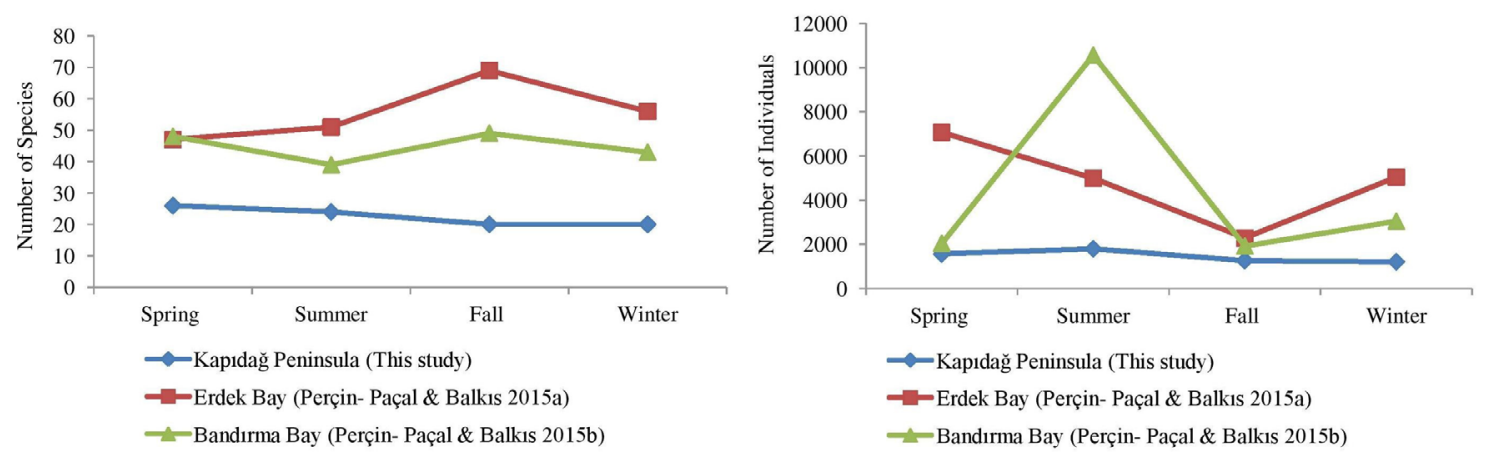

Figure 6. Seasonal numbers of ostracod species and numbers of individuals determined in the current study compared to other studies. 
$[28,33]$. No correlation was detected between this species and our ecological parameters.

Loxoconcha stellifera was observed at 0.5-30 m depths in this study, in high numbers and at a frequency of $75.0 \%$, from mesohaline to polyhaline conditions. The species has been observed at 3.5-33 m on muddy and sandy sediments in the Aegean Sea [28,33]. It also lives in the littoral and sublittoral zones of most Turkish coasts [21]. A positive correction was observed between this species and dissolved oxygen.

Although Paradoxostoma fuscum is not found widely on Turkish coastlines [21], we observed this species at all the stations, from mesohaline to polyhaline conditions at $64.3 \%$ frequency. No correlation was detected between this species and the ecological parameters.

A greater number of ostracod species and individuals were observed in the Bandırma and Erdek bays at the same depths in the years of 2006-2007 [23,24]. When the current study's findings on habitat variables are compared with the studies mentioned above, it was noted that DO, salinity, and temperature were lower in the current study (Table 7).

In 2008, an environmental problem occurred due to the formation of mucilage formed by the proliferation of diatoms together with bacteria throughout the Sea of Marmara. Some studies stated that because of this, Iiving creatures in the Sea of Marmara were adversely affected $[49,50]$. This could explain the decrease in ostracod species and the number of individuals and changes in ecological parameters since the previous research on Kapıdağ Peninsula. [22-24].

Although the measured average DO was at appropriate survival levels in this study, it decreased to $1.2 \mathrm{mgL}^{-1}$ at W-3 and W-4 stations, especially during winter. It has been observed in general that DO significantly decreases with depth in all seasons. In previous studies, although the measured DO was higher, the decrease of DO with depth has been observed in Bandırma Bay and Erdek Bay $[23,24]$. It is well known that the DO in surface waters is higher due to photosynthetic activities and DO reduces with depth. Increase of phytoplankton biomass in response to excessive inputs of nutrients and higher organic loads in eutrophic systems lead to an increase in bacterial activity and a decrease in DO levels [51]. When the DO level falls below $5 \mathrm{mgL}^{-1}$, oxygen-sensitive inver- tebrate and fish species are negatively affected [52]. The amount of the DO measured in the current study was lower than in previous studies [23,24]; therefore, the adverse effects of low DO on organisms that live in the study area of the Kapıdağ Peninsula are inevitable.

Secchi disk visibility in oligotrophic waters is $20-40 \mathrm{~m}$, in mesotrophic waters 10-20 m, and in eutrophic waters, less than $10 \mathrm{~m}$ [53]. Secchi depths ranged between 0.5 and $13 \mathrm{~m}$ in the current study. These values show that the study area is in the mesotrophic water category. The Secchi depth measurements from this study are very similar to previous ones: $3-13 \mathrm{~m}$ in the Bandırma and Erdek bays in the years of 2006-2007 [23-24].

Erdek Bay and Bandırma Bay are affected by heavy pollutants coming from numerous industrial facilities and human settlements [50]. The northeastern part of Kapıdağ Peninsula contains higher levels of phosphates than other regions [50]. Waters from Susurluk River and Kara River spill into Bandırma Bay and pollute the surface waters [50]. The presence of a white-meat processing plant and a fertilizer factory also causes intense pollution in this region [54]. According to the Integrated Coastal Area Plan of Bursa Province (2015) [55], the Sea of Marmara is less polluted, but Bandırma Bay and Gemlik Bay are at a mid-level stage polluted and were found to be prone to intense pollution. As can be inferred from the results of the current study, the decrease in the number of ostracod species and individuals and the decrease in the quality of the environmental variables (DO, salinity, and temperature) suggest that negative changes in the water quality of Kapıdağ Peninsula's coastline are because of pollution. These polluted environments allow for the advance of cosmopolitan species with wide ecological tolerance through the elimination of low-tolerance species. Already, the existence of environmental tolerant species L. stellifera [56,57], $A$. prasina [57], L. rhomboidea [56,57], and X. aurantia [57] and the reduction of the number of ostracod species are suggested by our findings.

Although the results of this study have not been thoroughly evaluated in terms of pollutants on the surface waters, the results show that the Kapıdağ Peninsula coastline has an ecosystem that requires measurement in terms of pollutants.

The present study establishes a sharp decline in ostracod species numbers. This evident decline can be attri- 
Table 7. Comparative ecology of the Kapıdağ Peninsula coastline (this study 2011-2012) and the Erdek and Bandırma bays in the years of 2006-2007 [23,24].

\begin{tabular}{|c|c|c|c|c|}
\hline Depth & $\begin{array}{l}\text { Ecological } \\
\text { Parameters }\end{array}$ & $\begin{array}{l}\text { Kapıdağ Peninsula } \\
\text { This study } \\
\text { (2011-2012) } \\
\text { (Mean values) }\end{array}$ & $\begin{array}{c}\text { Erdek Bay [23] } \\
(2006-2007) \\
\text { (Mean values) }\end{array}$ & $\begin{array}{c}\text { Bandırma Bay [24] } \\
\text { (2006-2007) } \\
\text { (Mean values) }\end{array}$ \\
\hline \multirow{6}{*}{$0-0.5 \mathrm{~m}$} & Salinity (\%o) & 20.3 & 24.8 & 24.5 \\
\hline & Dissolved oxygen (mg/l) & 6.9 & 10 & 9.6 \\
\hline & Temperature $\left({ }^{\circ} \mathrm{C}\right)$ & 16.4 & 17.7 & 17.4 \\
\hline & Total organic carbon (\%) & 0.8 & 0.4 & 0.4 \\
\hline & Total calcium carbonate (\%) & 2.8 & 4.8 & 4.1 \\
\hline & Mud percentage (\%) & 0.5 & 0.39 & 1.09 \\
\hline \multirow{6}{*}{$1 \mathrm{~m}$} & Salinity (\%o) & 20.7 & 24.7 & 24.2 \\
\hline & Dissolved oxygen (mg/l) & 6.8 & 8.9 & 9.1 \\
\hline & Temperature $\left({ }^{\circ} \mathrm{C}\right)$ & 15.2 & 16.9 & 17.5 \\
\hline & Total organic carbon (\%) & 0.7 & 0.5 & 0.5 \\
\hline & Total calcium carbonate (\%) & 2.7 & 2.6 & 1 \\
\hline & Mud percentage (\%) & 21.7 & 4.96 & 1 \\
\hline \multirow{6}{*}{$5 \mathrm{~m}$} & Salinity (\%o) & 21.4 & 25 & 24.9 \\
\hline & Dissolved oxygen (mg/l) & 6.3 & 8.1 & 8.4 \\
\hline & Temperature $\left({ }^{\circ} \mathrm{C}\right)$ & 14.9 & 16.2 & 16.1 \\
\hline & Total organic carbon (\%) & 0.8 & 0.7 & 0.4 \\
\hline & Total calcium carbonate (\%) & 3 & 62.8 & 1.3 \\
\hline & Mud percentage (\%) & 19.9 & 15.82 & 1.5 \\
\hline \multirow{6}{*}{$10 \mathrm{~m}$} & Salinity (\%o) & 21.8 & 25.2 & 25.7 \\
\hline & Dissolved oxygen (mg/l) & 6.7 & 7.6 & 8.1 \\
\hline & Temperature $\left({ }^{\circ} \mathrm{C}\right)$ & 14.3 & 15.8 & 16.5 \\
\hline & Total organic carbon (\%) & 1.1 & 1.3 & 1.6 \\
\hline & Total calcium carbonate (\%) & 7 & 71.1 & 17.1 \\
\hline & Mud percentage (\%) & 29.5 & 37.24 & 31 \\
\hline \multirow{6}{*}{$20 \mathrm{~m}$} & Salinity (\%o) & 24.1 & 30.2 & 27.7 \\
\hline & Dissolved oxygen (mg/l) & 5 & 7.2 & 7.8 \\
\hline & Temperature $\left({ }^{\circ} \mathrm{C}\right)$ & 12 & 14.1 & 13.5 \\
\hline & Total organic carbon (\%) & 1.7 & 0.8 & 1.2 \\
\hline & Total calcium carbonate (\%) & 30.8 & 48.7 & 57.9 \\
\hline & Mud percentage (\%) & 24.4 & 47.07 & 48.03 \\
\hline \multirow{6}{*}{$30 \mathrm{~m}$} & Salinity (\%o) & 27.5 & 36 & 35.5 \\
\hline & Dissolved oxygen (mg/l) & 4.5 & 6 & 6.3 \\
\hline & Temperature $\left({ }^{\circ} \mathrm{C}\right)$ & 14.1 & 15.5 & 15.4 \\
\hline & Total organic carbon (\%) & 2.1 & 1.5 & 2.4 \\
\hline & Total calcium carbonate (\%) & 7.2 & 14.1 & 11.9 \\
\hline & Mud percentage (\%) & 31.6 & 91.02 & 85.99 \\
\hline
\end{tabular}


buted to low dissolved oxygen levels at depth, which is evidence of the adverse effects of anthropogenic activities on the marine ecosystem on the Kapıdağ Peninsula coastline.

\section{References}

1. D.J. Horne, A. Cohen, K. Martens, Taxonomy, morphology and biology of Quaternary and living Ostracoda. In: The Ostracoda: Applications in Quaternary Research (J.A Holmes and A.R. Chivas, Eds.), American Geophysical Union, Washington, DC. (2002) 5-36.

2. T. Salel, H. Bruneton, D. Lefèvre, Ostracods and environmental variability in lagoons and deltas along the north-western Mediterranean coast (Gulf of Lions, France and Ebro delta, Spain), Review of Micropaléontology. 59 (2016) 425-444.

3. W.T.R. Chiu, M. Yasuhara, H. Iwatani, A. Kitamura, K. Fujita, Response of subtropical submarine-cave ecosystem to Holocene cave development and Asian monsoon variability, Paleobiology, 43 (2017) 425-434.

4. M. Yasuhara, T.M. Cronin, Climatic influences on deep sea ostracode (Crustacea) diversity for the last three million years, Ecology, 89 (2008) 52-65.

5. C. Meisc, Freshwater Ostracoda of Western and Central Europe.-In J Schwoerbel and P. Zwick, Editors: Süßwasserfauna von Mitteleuropa 8/3. Spektrum Akademischer Verlag, Heidelberg, Berlin. (2000) 522 pp.

6. P. Frenzel, I. Boomer, The use of ostracods from marginal marine, brackish waters as bioindicators of modern and Quaternary environmental change. Palaeogeography, Palaeoclimatology, Palaeoecology, 225 (2005) 68-92.

7. F. Mesquita-Joanes, A.J. Smith, F.A. Viehberg, The ecology of Ostracoda across levels of biological organisation from individual to ecosystem: a review of recent developments and future potential. In: Ostracoda as Proxies for Quaternary Climate Change (D.J. Horne, J. Holmes, J. Rodriguez Lazaro and F.A. Viehberg, eds.), (2012). pp. 15-35. Elsevier, Amsterdam.

8. J.W. Neale, Some factors influencing the distribution of Recent. British Ostracoda. Publ. Staz. Zool. Napoli 33 (Suppl.) (1964) 247-296.

9. F. Ruiz, M. Abad, A.M. Bodergat, P. Carbonel, J. RodríguezLázaro, M.L. González-Regalado, A. Toscano, E.X. García, J. Prenda, Freshwater ostracods as environmental tracers, I. J. Environ. Sci. Technol., 10 (2013) 1115-1125.

10. Y. Hong, M. Yasuhara, H. Iwatani, Seto K., Yokoyama Y., Yoshioka K.B. Mamo, Freshwater reservoir construction by damming a marine inlet in Hong Kong: Paleoecological evidence of local community change, Marine Micropaleontology, 132 (2017) 53-59.

11. F. Ruiz, M. Abad, A.M. Bodergat, P. Carbonel, J. RodríguezLázaro, M. Yasuhara Marine and brackish-water ostracods as sentinels of anthropogenic impacts, Earth-Sci. Rev., 72 (2005) 89-111.

12. M. Yasuhara, H. Yamazaki A. Tsujimoto, K. Hirose, The effect of long-term spatiotemporal variations in urbanizationinduced eutrophication on a benthic ecosystem, Osaka Bay, Japan, Limnol. Oceanogr., 52 (2007) 1633-1644.

13. A.M. Bodergat, M. Rio, N. Ikeya, Tide versus eutrophication, impact on ostracods populations structure of Mikawa Bay (Japan), Revue de Micropale'ontlogie, 40 (1997) 3-13.
14. F. Mezquita, R. Hernandez, J. Rueda, Ecology and distribution of ostracods in polluted Mediterranean River, Palaeogeography, Palaeoclimatology, Palaeoecology 148 (1999) 87-103.

15. F. Ruiz, M.L. Gonza'lez-Regalado, J.M. Munoz, Multivariate analysis applied to total and living fauna: seasonal ecology of recent Ostracoda off the North Cadiz Gulf coast (southwestern Spain), Marine Micropaleontology, 31 (1997) 183-203.

16. F. Ruiz, M.L. Gonza'lez-Regalado, J.I. Baceta, J.M. Munoz, Comparative ecological analysis of the ostracod faunas from low- and high-polluted southwestern Spanish estuaries: a multivariate approach, Marine Micropaleontology, 40 (2000) 345-76

17. M. Yasuhara, H. Yamazaki, T. Irizuki, S. Yoshikawa, Temporal changes of ostracode assemblages and anthropogenic pollution during the last 100 years, in sediment cores from Hiroshima Bay, Japan. Holocene, 13 (2003) 527-536.

18. Ş.T. Beşiktepe, H.I. Sur, E. Özsoy, M.A. Abdullatif, T. Oğuz, Ü. Ünlüata, The circulation and hydrography of the Marmara Sea, Progress in Oceanography., 34 (1994) 285-334.

19. H. Yüce, A. Türker, Marmara Denizi'nin fiziksel oşinografik özellikleri ve Akdeniz suyunun Karadeniz'e girişi, Uluslararası Çevre Sorunları Sempozyumu Tebliğleri, İstanbul Marmara Rotary Kulübü, İstanbul, (1991) 284-303.

20. F. Perçin-Paçal, S. Altınsaçlı, H. Balkıs "Recent Ostracoda Species of the Sea of Marmara with Çanakkale (Dardanelles) and İstanbul Strait (Bosphorus): A Review", The Sea of Marmara: Marine Biodiversity, fisheries, conservation and governance, E. Özsoy, M.N. Çağatay, N. Balkıs, N. Balkıs, B. Öztürk, Ed., TUDAV, Istanbul, (2016) 454-467.

21. F. Perçin-Paçal, S. Altınsaçlı, H. Balkıs An updated checklist of recent marine and coastal brackish water ostracods (Crustacea Ostracoda) in Turkey.,J. Entomology and Zoology Studies, 3 (2015) 20-33.

22. F. Perçin-Paçal, H. Balkıs, Seasonal Distribution of Ostracoda in Bandırma Bay and Erdek Bay, Sea of Marmara, Turkey, Crustaceana, 85 (2012) 847-875.

23. F. Perçin-Paçal, H. Balkıs, The Ecology of Ostracoda (Crustacea) Species Obtained From Erdek Bay (The Marmara Sea, Turkey) International Journal of Environmental Research. 9 (2015 a) 1245-1258.

24. F. Perçin-Paçal, H. Balkıs, Environmental and Ecological Assessment of Ostracods inhabiting in Bandırma Bay, The Marmara Sea, Turkey, I. J. Fisheries and Aquatic Studies, 2 (2015) 285-299.

25. Strategic Plan, The Bandırma Chamber of Commerce 20182021. Strategic Plan was approved by the decision of the board of directors dated 13.03.2018 and numbered (2018) 245.

26. D.D. Mordukhai-Boltovskoi, Ostracoda of the Black Sea from determination of the fauna of the Black and Azov Seas (in Russian). Kiev, Kievskaya Kni/linaya Fabrika; (1969) 1-82.

27. E.I. Schornikov, Ostracoda, Führer der fauna des. Schwarzen Meers und der Azov Sea. In Frielbenden invertebraten (ed. A.A. Vodyanistskii), Crustacean. Akademii Nauk. U.S.S.R. Institute. Biology, Naukova. Dumka Kiev, (1969) 163-260.

28. P.J. Barbeito-Gonzalez, Die Ostracoden des Künstenbereiches von Naxos (Griechenland) und ihre Lebensbereiche. Mitteilungen aus dem von Naxos (Griechenland) und ihre Lebensbereiche, Mitteilungen aus dem Hamburgischen Zoologischen Museum und Institut. 67 (1971) 255-326. 
29. G. Hartmann, S.H. Puri, Summary of neontological and paleontological classification of Ostracoda, Mitteilungen aus dem Hamburgischen Zoologischen Museum und Institut, Band, 70 (1974) 7-73.

30. G. Bonaduce, G. Ciampo, M. Masoli, Distribution of Ostracoda in the Adriatic Sea, Publicazioni Della Stazione Zoologica di Napoli; 40 (1975) 1-154.

31. J. Athersuch, D.J. Horne, J.E. Whittaker, Marine and brackish water ostracods. In: Kermack D.M. and Barnes R.S.K. (eds.) Synopses of the British Fauna (New Series), No. 43, E.J. Brill, Leiden (for the Linnean Society of London and the Estuarine and Brackish Water Sciences Association), (1989) 361 pp.

32. I. Yassini, The littoral system ostracodes from the Bay of Bou-ismail, Algiers, Algeria Rev. Revista Espanola Micropaleontology, 3 (1979) 353-416.

33. A. Stambolidis, Zur Kenntnis Der Ostracodes des Evros-Delta (Nord-Agaisches Meer) Griechenland, Mitteilungen aus dem Hamburgischen Zoologischen Museum und Institut, 82 (1985) 155-254.

34. WoRMS, World Register of Marine Species (http://www. marinespecies.org/aphia.php? $\quad$ =taxdetails\&id=1078) (2018).

35. L.W. Winkler, The determination of dissolved oxygen in water, Berichte der Deutschen Chemischen Gesellschaft., 21 (1888) 2843-2855.

36. A. Ivanoff, Introduction à l'océanographie, Tome I. Librairie Vuibert, Paris (1972) .

37. L.R. Folk, Petrology of Sedimentary Rocks, Hemphill, Tulsa, Oklahama (1974)

38. H. Gaudette, W. Flight, L. Tanner, D. Folger, An Expensive titration method for the determination of organic carbon in recent sediments, J. Sedimentary Petrology, 44 (1974) 249253.

39. D.H. Loring, R.T.T. Rantala, Manuel for the Geochemical Analyses of Marine Sediments and Suspended Particulate, Matter. Earth Science Reviews, 32 (1992) 235-283.

40. N. McAleece, J.D.G. Gage, P.J.D. Lambshead, G.L.J. Paterson, BioDiversity Professional Statistics Analysis Software. Jointly developed by the Scottish Association for Marine Science and the Natural History Museum London, The Natural History Museum and The Scottish Association for Marine Science, Oban (1997).

41. A. Kocataş Ekoloji ve çevre biyolojisi.(Ecology and environmental biology) Üçüncü baskı. Ege Üniversitesi, Su Ürünleri Fakültesi Yayınları, No: 20. Ege University Press, Bornova, İzmir (1996).

42. M. Mahajan, S. Fatima, Frequency, Abundance and Density of Plant Species by List Quadrat Method. Epitome, International Journal of Multidisciplinary Research, 3 (2017) 7, ISSN: 2395-6968.

43. IBM Corp. Released, IBM SPSS Statistics for Windows, Version 21.0. Armonk, NY: IBM Corp. (2012).

44. C.J.F. Ter Braak, Canonical correspondence analysis: A new eigenvector technique for multivariate direct gradient analysis, Ecology, 67 (1986) 1167-1179.
45. W. Kovach, MVSP - A MultiVariate Statistical Package, MVSP Version 3.22, Kovach Computing Services, Pentraeth, Wales, U.K. (2013).

46. S. Hull, Seasonal changes in diversity and abundance of ostracods on four species of intertidal algae with differing structural complexity, Marine Ecology Progress Series, 161 (1997) 71-82.

47. I. Mazzini, P. Anadon, M. Babieri, F. Castorina, L. Ferrelid, E. Gliozzie, M. Molae E.Vittorif, Late Quaternary sea-level changes along the Tyrrhenian coast near Orbetello (Tuscany, central Italy): palaenvironmental reconstruction using ostracods, Marine Micropaleontology, 37 (1999) 289-311.

48. F. Perçin-Paçal, The ecology of the Ostracoda (Crustacea) species obtained from the coasts of İskenderun Bay (Eastern Mediterranean Sea), J. Black Sea/Mediterranean Environment., 17 (2011) 127-144.

49. N. Balkıs, H. Atabay, I. Türetgen, S. Albayrak, H. Balkıs V. Tüfekçi, Role of single-celled organisms in mucilage formation on the shores of Büyükada Island (the Marmara Sea), J. Marine Biological Association of the United Kingdom, 91 (2011) 771-781.

50. N. Balkıs, B. Toklu-Alıçı, M. Balcı, Evaluation of Ecological Quality Status with the Trophic Index (TRIX) Values in the Coastal Waters of the Gulfs of Erdek and Bandırma in the Marmara Sea Ecological Water Quality-Water Treatment and Reuse, Dr. Voudouris (Ed.), (2012) ISBN: 978-953-510508-4.

51. M. Karydis, Eutrophication assessment of coastal waters based on indicators: a literature review, Global NEST J., 11 (2009) 373-390.

52. J.D. Frodge, G.L. Thomas G.B. Pauley, Effects of canopy formation by floating and submergent aquatic macrophytes on the water quality of two shallow Pacific Northwest lakes. Aquatic Botany, 38 (1990) 231-248.

53. L. Ignatiades, D. Georgopoulos, M. Karydis, Description of a phytoplanktonic community of the oligotrophic waters of SE Aegean Sea (Mediterranean), Marine Ecology, 16 (1995) 13-26.

54. T. Koç, Bandırma ilçesinde tavukçuluğun çevresel etkisi, Ekoloji, 11 (2002) 11-16.

55. Ministry of Environment and Urban, General Directorate of Spatial planning, "Integrated coastal area plan of Bursa province, Plan statement report.", (2015) 1-74 pp.

56. D. Arbulla, N. Pugliese, A. Russo, Ostracods from the National Park of La Maddalena Archipelago (Sardinia, Italy) Bulletino della Societa Paleontologica Italiana 43 (2004) 91-99.

57. S. Altınsaçlı, F. Perçin-Paçal, S. Altınsaçlı, Assessments on diversity, spatiotemporal distribution and ecology of the living ostracod species (Crustacea) in oligo-hypersaline coastal wetland of Bargilya (Milas, Muğla, Turkey, I. J. Fisheries and Aquatic Studies, IJFAS, 3 (2015) 357-373. 